\title{
9. GRAIN-SIZE OF THE BLACK SEA SEDIMENTS, DSDP LEG 42B
}

\author{
E. S. Trimonis and K. M. Shimkus, P. P. Shirshov Institute of Oceanology, \\ USSR Academy of Sciences, Kaliningrad, USSR
}

\section{INTRODUCTION AND TECHNIQUE}

Samples obtained during DSDP Leg 42B represent a section of late Cenozoic and Pleistocene sediments in the eastern part and southwestern part of the Black Sea Basin. Grain-size analyses of the sediments were made on 318 samples from Holes 379A, 380/380A, and 381. Most of the analyses were done in the Atlantic and Southern branches of the P. P. Shirshov Institute of Oceanology, USSR Academy of Sciences (analysts were G. V. Zhuravleva, A. I. Panikhina, and F. D. Stukanog); 30 samples from Holes 380/380A were analyzed under the guidance of M. P. Nesterova in the Institute of Oceanology. Some thin sections of lithified sediments were studied with the participation of A. S. Zhigunov.

Grain-size analyses were carried out by the watermechanical method using suspensional balances (Petelin, 1961; Prokoptsev, 1964). For the purpose of better dispersion of sedimentary material and its separation into fractions, samples were boiled with pyrophosphate. The sediments are divided into six granulometric fractions: $>0.1 \mathrm{~mm}$ (sand); $0.1-0.5 \mathrm{~mm}$ (coarse aleuritic silt); 0.05-0.01 mm (fine aleuritic silt); 0.01-0.005 mm (coarse pelitic); 0.005-0.001 mm (medium pelitic); $<0.001 \mathrm{~mm}$ (subcolloidal). The sum of $<0.01 \mathrm{~mm}$ fractions is referred to as pelitic material. Median diameters (Md) and sorting coefficient (So) of sediments are estimated according to cumulative curves constructed on semilogarithmic paper by A. P. Lisitzin's method (Lisitzin, 1956). Granulometric sediment types are distinguished on the basis of predominant fraction and Md of sediments (Table 1). Among pelitic muds containing more than 70 per cent of the $<0.01 \mathrm{~mm}$ fraction we distinguish $>90$ per cent of $<0.01$ $\mathrm{mm}$ fraction as finely dispersed pelitic muds.

\section{DISCUSSION OF RESULTS}

Lithological investigations of modern sediments carried out on R/V Academician S. Vavilov in the vicinity of Hole 379A (Figure 1), showed great non-uniformity not only of mineralogical content but also granulometric fractions (Table 2). Clay (Station 2257, Station 2258), high-calcareous nannofossil oozes (Station 2291-3), fine-silty muds (Station 2259), and coarse silts (Station 2293-3) occur in different locations of the polygon investigated. It is possible that the considerable thickness $(>3 \mathrm{~m})$ of well-sorted coarse silts at the latter site is partly the result of leakage into the piston tube. The layer consists of two thick, size-graded rhythms in which the Md of sediments in the lower rhythm decreases upwards from 0.075 to $0.060 \mathrm{~mm}$ and, in the upper one, from 0.095 to $0.055 \mathrm{~mm}$ (Table 2). The upper parts of the rhythms are more poorly sorted (So $=2.2-2.5$ ) than the lower parts $($ So $=1.4-1.8)$.

The grain-size profiles of pelitic muds (clays) are not uniform. Subcolloidal and medium-pelitic fractions domi-
TABLE 1

Classification of Marine Sediments (after P. L. Bezrukoy and A. P. Lisitzin, 1960)

\begin{tabular}{clcc}
\hline & Grain-Size Types & $\begin{array}{c}\text { Size of Prevalent } \\
\text { Fraction }(\mathrm{mm})\end{array}$ & $\mathrm{Md}(\mathrm{mm})$ \\
\hline \multirow{2}{*}{$\begin{array}{c}\text { Sandy sediments } \\
\text { (psammits) }\end{array}$} & $\begin{array}{c}\text { Sands: } \\
\text { coarse }\end{array}$ & $1-0.5$ & $1-0.5$ \\
& \multicolumn{1}{c}{ medium } & $0.5-0.25$ & $0.5-0.25$ \\
fine & $0.25-0.1$ & $0.25-0.1$ \\
$\begin{array}{c}\text { Silty sediments } \\
\text { (aleurites) }\end{array}$ & Coarse silts & $0.1-0.05$ & $0.1-0.05$ \\
$\begin{array}{c}\text { Clayey sediments } \\
\text { (pelites) }\end{array}$ & Silty clay & $0.1-0.01$ & $0.05-0.01$ \\
& (aleurite-pelitic mud) & $\begin{array}{c}\text { less than } 0.01 \\
(<70 \%)\end{array}$ & $0.01-0.007$ \\
& Clay & less than 0.01 & $<0.007$ \\
& (pelitic mud) & $(>70 \%)$ & \\
\hline
\end{tabular}

nate at Station 2257, and coarse-pelitic is predominant at Station 2258. Subcolloidal fraction prevails in nannofossil oozes (Station 2291-3).

The Holocene lithology is also heterogeneous (Table 2); the upper Holocene subhorizon is characterized by interbedded clay, silty-clay, nannofossil ooze, and fine-silty muds, whereas the middle Holocene (Old Black Sea) subhorizon contains sapropelic oozes instead of nannofossil oozes and consists of silty clay and fine silty muds.

The highest contents of pelitic material occur in nannofossil oozes at Station 2291-3. Gradual changes from fine silty muds to silty clay muds (Horizon $205-215 \mathrm{~cm}$ ) and from silty clay to clay (Horizon 7-35 cm, 78-90 cm) occur within this core. In addition, gradual increase of dispersion upwards is observed in the layer of silty clays of Station 2259 (Horizon 203-218 cm).

The size grading of silts and clays and their good sorting indicate a turbidity origin. During the Holocene, turbidity currents apparently penetrated into the central areas of the Black Sea transporting considerable amounts of matter from the peripheral zone of the basin. They occur mostly in the eastern part of the basin (Shimkus et al., 1975). Grain-size rhythms consisting of coarse silts, fine silty and silty clayey muds are distinguished at some intervals of Core 4750-2 obtained east of the drilling region (Table 2).

\section{SITE 379}

The grain size of Pleistocene deposits in Hole 379A is given in Table 3 and Figures 2 and 3 . In the upper part of the sequence, corresponding to the Würm period (Unit 3), terrigenous mud and silty clay prevail. The medium-pelitic and subcolloidal fractions dominate over clays and muds, but as a whole, the pelitic material content is not high. A wide range in the grain-size profile for silty clay is apparent. In some cases it is close to pelitic muds (Sample 6-2, 32-38 cm), and sometimes to fine silty ones (Sample 6-6, 0-2 cm).

Interbeds of coarse-grained material (sands, silts) with obvious size-grading were encountered in Würm sediments (Cores 1-1, 1-2, 4-4, 4-5). Such layers are components of 


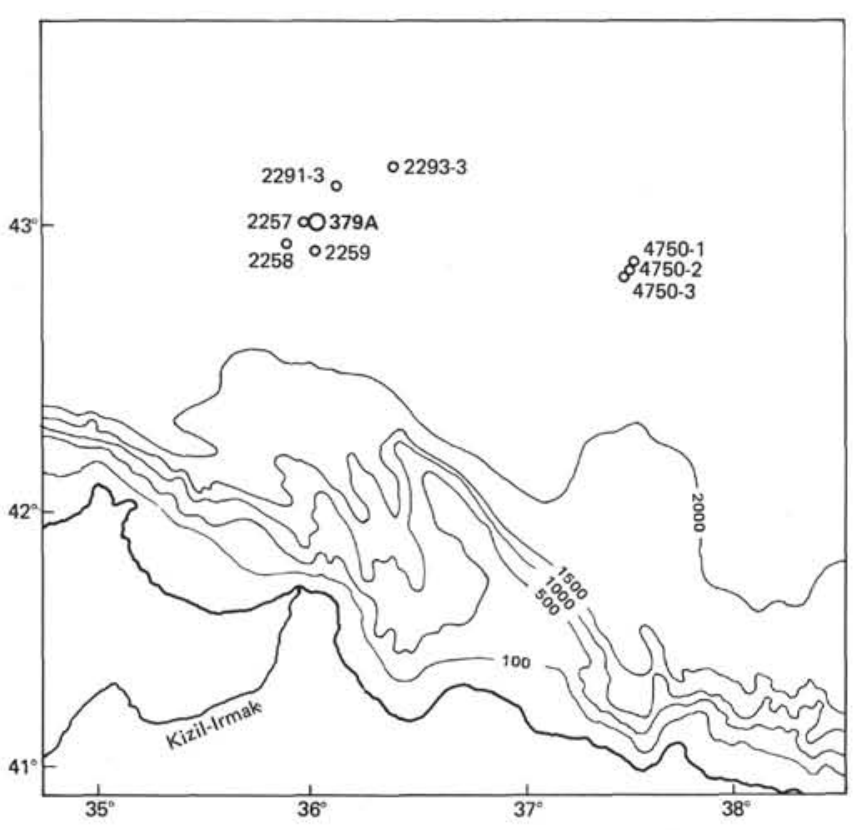

Figure 1 (A) Leg $42 B$ sites and late Quaternary sediment core locations.

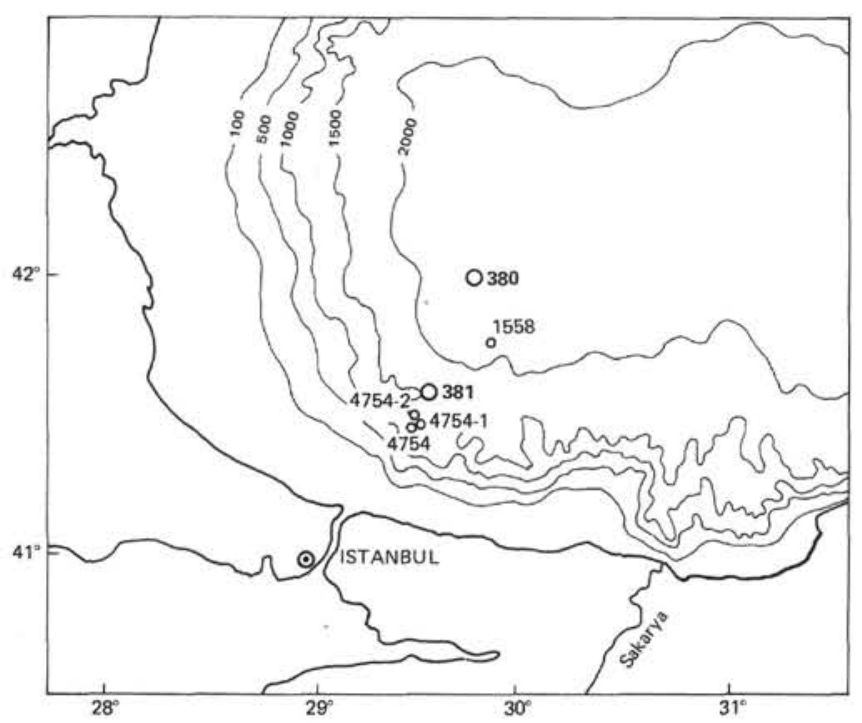

Figure 1 (B) Leg $42 B$ sites and late Quaternary sediment core locations.

turbidites typical of deposits in the eastern part of the Black Sea deep depression. Turbidites formed at the end of late Würm occur in almost all cores here (Emelyanov and Shimkus, 1963; Shimkus et al., 1975). In detail, Core 4750-3 taken east of Hole 379A shows a set of size-grading rhythms which consist of: (1) fine-grained sands, coarse silts (123$126 \mathrm{~cm}, 151-239 \mathrm{~cm}, 428-495 \mathrm{~cm}, 646-940 \mathrm{~cm})$ and sometimes fine-silty muds $(579-593 \mathrm{~cm})$; (2) coarse silts, fine silty muds, silty clay and clay $(345-402 \mathrm{~cm})$; and (3) fine silty muds and silty clay $(51-101 \mathrm{~cm})$ (Table 2$)$.

In some intervals (i.e., Sample 6-5, 36-46 cm) separate microinterbeds of granulometrically different material occur. The fine aleuritic fraction is dominant, but there is a considerable admixture of coarse silt and sand (Table 3 ).
Riss-Würm deposits (Units 4 and 5) are represented by coarse silts, fine silty and aleurite-pelitic muds depending on their lithologic composition. Parts are enriched in diatoms, others in coccoliths (nannofossil oozes) as well as in terrigenous sandy silty material. The fine aleuritic fraction together with either pelitic (silty clay) or sandy and coarse silt fractions (coarse silts) usually prevails in the grain-size profile.

A variety of granulometric types from pelitic muds to fine-grained sands, occurs in the Riss deposit sequence (Unit 6). Medium pelitic and subcolloidal fractions are usually predominant in the pelitic sediments. The relatively low content of pelitic material is characteristic of the samples studied. The fine aleuritic fraction together with medium pelitic (aleurite-pelitic mud) or with sandy and coarse aleuritic (coarse silts) fractions dominate over other granulometric sediment types; only in fine-grained sands (Sample 16-2, $50-52 \mathrm{~cm}$ ) does the sandy fraction predominate.

Size-grading occurs in the lower part of the Riss deposits profile beginning at Core 19. As an example, in Sample 24-4, $133-141 \mathrm{~cm}$, the fine material content gradually increases from the base of the interbed toward its top, and the Md decreases from 0.015 to $0.009 \mathrm{~mm}$ (Table 3). Two successive granulometric rhythms are found in Sample 19-3, 83-98 $\mathrm{cm}$. In the lower interval part $(85-98 \mathrm{~cm})$ pelitic muds are gradually enriched in pelitic material, and at the $83-85 \mathrm{~cm}$ interval fine silty muds are sharply substituted by pelitic ones. Grain-size rhythms suggest a determinant role of turbidity currents in forming not only coarse-grained deposits but also partly pelitic muds.

The Mindel-Riss deposits (Unit 7) are characterized by the most finely dispersed pelitic muds (Samples 26-4, 0-12 cm and $27-3,145-147 \mathrm{~cm}$ ), where the medium pelitic and subcolloidal fractions prevail. A further characteristic feature is the high content of the coarse pelitic fraction $(45.20 \%$ $51.33 \%$ ) in Samples 24-6, 62-74 cm and 25-7, 142-144 cm. Approximately the same content of the coarse pelitic fraction is found in the surface layer of pelitic muds at Station 2258 in the drilling area (Table 2). As a whole, Recent Black Sea sediments contain small amounts of coarse-pelitic material (Trimonis, 1972). The high contents of coarse-pelitic fraction are not encountered elsewhere in Hole 379A.

In aleurite-pelitic and fine silty muds, the fine-aleuritic fraction is most prevalent; between 53.20-73.03 per cent was observed in fine silty muds with good to medium sorting (Table 3).

Size-graded rhythms indicative of turbidity currents are found in the sequence of Mindel-Riss deposits. In Sample $29-5,98-112 \mathrm{~cm}$ fine to silty muds are substituted by pelitic ones, and in Sample $28-6,70-80 \mathrm{~cm}$, finely dispersed material increases gradually upwards, and the Md decreases from 0.045 to $0.009 \mathrm{~mm}$. Similar size-grading rhythms are discovered in Samples 27-5, 53-60 cm, 26-2, 20-29 cm, and 25-3, $120-129 \mathrm{~cm}$.

Mindel terrigenous deposits (Unit 8) are represented by pelitic, aleurite-pelitic and fine silty muds. Interbeds of sandy silt deposits (turbidites) often occur throughout the sequence. Finely dispersed pelitic muds are also present (Samples 38-6, 18-20 cm, 40-2, 138-140 cm). In the grainsize profile of the pelitic muds the subcolloidal fraction or medium pelitic prevails; as a rule, the fine aleuritic fraction is increased. 
TABLE 2

Grain-Size Analyses of Holocene and Upper Würm Sediments in the Areas of DSDP Leg 42B Sites 379, 380, and 381

\begin{tabular}{|c|c|c|c|c|c|c|c|c|c|c|c|c|c|}
\hline $\begin{array}{l}\text { Horizon } \\
(\mathrm{cm})\end{array}$ & $>0.1^{\mathrm{a}}$ & $\begin{array}{l}0.1^{-} \\
0.05\end{array}$ & $\begin{array}{l}0.05- \\
0.01\end{array}$ & $\begin{array}{l}0.01- \\
0.005\end{array}$ & $\begin{array}{l}0.005- \\
0.001\end{array}$ & $<0.001$ & $<0.01$ & $(\mathrm{~mm})$ & So & $\begin{array}{c}\mathrm{CaCO}_{3} \\
(\%)\end{array}$ & $\begin{array}{l}\mathrm{C}_{\text {org }} \\
(\%)\end{array}$ & Type of Sediments & Age \\
\hline \multicolumn{14}{|c|}{ Station $2257,43^{\circ} 00^{\prime} \mathrm{N}, 36^{\circ} 00^{\prime} \mathrm{E}$, depth 2163 meters } \\
\hline $19-25$ & $\operatorname{tr}$. & 0.13 & 35.01 & 22.99 & 16.92 & 24.93 & 64.84 & 0.0069 & 3.7 & - & - & Silty clay & $\mathrm{Hl}$ III \\
\hline \multicolumn{14}{|c|}{ Station $2258,42^{\circ} 57^{\prime} \mathrm{N}, 35^{\circ} 55^{\prime} \mathrm{E}$, depth 2173 meters } \\
\hline $\begin{array}{c}0-3 \\
3-15 \\
15-25\end{array}$ & $\begin{array}{l}0.14 \\
\text { tr. } \\
\text { tr. }\end{array}$ & $\begin{array}{l}\text { tr. } \\
2.17 \\
0.36\end{array}$ & $\begin{array}{l}24.60 \\
52.32 \\
29.68\end{array}$ & $\begin{array}{l}40.14 \\
17.55 \\
26.22\end{array}$ & $\begin{array}{l}14.96 \\
10.18 \\
21.45\end{array}$ & $\begin{array}{l}20.14 \\
17.76 \\
22.29\end{array}$ & $\begin{array}{l}75.24 \\
45.49 \\
69.96\end{array}$ & $\begin{array}{l}0.0069 \\
0.0110 \\
0.0051\end{array}$ & $\begin{array}{l}2.3 \\
2.4 \\
3.3\end{array}$ & - & $\begin{array}{l}- \\
-\end{array}$ & $\begin{array}{l}\text { Clay } \\
\text { Fine silty mud } \\
\text { Silty clay }\end{array}$ & $\begin{array}{l}\text { Hl III } \\
\text { Hl III } \\
\text { Hl III }\end{array}$ \\
\hline
\end{tabular}

Station $2259,42^{\circ} 54^{\prime} 8 \mathrm{~N}, 36^{\circ} 05^{\prime} 0 \mathrm{E}$, depth 2183 meters

\begin{tabular}{ccrrrrrrrrrrll}
$0-5$ & 0.20 & 5.97 & 59.88 & 6.46 & 15.36 & 12.13 & 33.95 & 0.018 & 2.6 & 22.63 & 1.24 & Fine silty mud \\
$10-15$ & 0.10 & 0.77 & 43.99 & 11.24 & 24.32 & 19.57 & 55.14 & 0.008 & 3.4 & 18.24 & 0.51 & Silty clay & HI III \\
$57-63$ & \multicolumn{1}{c}{ tr. } & 1.89 & 56.66 & 9.34 & 16.90 & 15.21 & 41.45 & 0.013 & 2.8 & - & - & Fine silty mud & HI III \\
$93-95$ & 0.10 & 9.91 & 72.98 & 2.62 & 7.87 & 6.51 & 17.01 & 0.015 & 1.8 & - & - & Fine silty mud III \\
$106-110$ & 2.20 & 4.64 & 67.10 & 5.85 & 12.21 & 9.99 & 28.06 & 0.017 & 1.8 & 14.71 & 0.43 & Fine silty mud \\
$174-178$ & tr. & 10.38 & 68.96 & 3.19 & 10.58 & 6.89 & 20.66 & 0.03 & 1.6 & 12.96 & 0.69 & Fine silty mud \\
$183-195$ & 0.61 & 2.61 & 21.50 & 15.21 & 31.34 & 28.72 & 75.28 & 0.003 & 3.6 & 4.10 & 17.61 & Sapropelic clay \\
$203-211$ & 0.30 & 0.41 & 36.14 & 10.25 & 31.57 & 21.32 & 63.15 & 0.0045 & 3.5 & 10.05 & 1.40 & Silty clay \\
$216-218$ & 0.19 & 1.23 & 40.08 & 12.19 & 27.22 & 19.09 & 58.50 & 0.0065 & 3.4 & - & - & Silty clay \\
$245-250$ & 0.20 & 0.10 & 32.27 & 14.08 & 33.71 & 19.63 & 67.43 & 0.004 & 3.4 & 25.16 & 0.56 & Silty clay & HI I \\
& & & & & & & HI I
\end{tabular}

Station $2291-3,43^{\circ} 08^{\prime} \mathrm{N}, 36^{\circ} 08^{\prime} \mathrm{E}$, depth 2151 meters

\begin{tabular}{|c|c|c|c|c|c|c|c|c|c|c|c|c|c|}
\hline $0-7$ & 0.19 & 0.77 & 17.66 & 3.84 & 32.63 & 44.91 & 81.39 & 0.0014 & 3.7 & 60.74 & 4.85 & Pelitic (nanno) ooze & HI III \\
\hline $25-35$ & 0.11 & 0.64 & 40.64 & 11.50 & 23.98 & 23.12 & 58.60 & 0.006 & 3.9 & - & - & Silty clay & H1 III \\
\hline $45-55$ & tr. & 0.31 & 30.74 & 12.88 & 27.41 & 28.66 & 68.95 & 0.006 & 3.7 & - & - & Silty clay & Hl III \\
\hline $45-56$ & tr. & 0.31 & 28.81 & 14.09 & 30.55 & 26.23 & 70.87 & 0.0035 & 3.7 & 19.12 & 0.80 & Clay & HI III \\
\hline $78-81$ & 0.08 & 0.17 & 16.01 & 9.05 & 39.40 & 35.29 & 83.74 & 0.0080 & 3.0 & 59.36 & 4.29 & Pelitic (nanno) ooze & HI III \\
\hline $81-90$ & 0.09 & 0.20 & 29.95 & 14.38 & 30.34 & 25.02 & 69.74 & 0.0040 & 3.3 & - & - & Silty clay & Hl II \\
\hline $105-115$ & 0.25 & 2.69 & 46.97 & 11.70 & 21.38 & 17.00 & 50.08 & 0.010 & 3.5 & 9.84 & 1.20 & Fine silty mud & Hl II \\
\hline $137-145$ & 6.63 & 38.94 & 38.56 & 4.42 & 8.46 & 2.98 & 15.86 & 0.045 & 2.0 & 10.60 & 0.63 & Fine silty mud & Hl II \\
\hline $205-215$ & 0.29 & 0.78 & 33.69 & 13.48 & 33.10 & 18.65 & 65.23 & 0.003 & 3.3 & 14.45 & 1.03 & Silty clay & Hl II \\
\hline $210-215$ & 0.21 & 6.75 & 55.06 & 10.26 & 16.15 & 11.56 & 37.97 & 0.015 & 2.4 & - & - & Fine silty mud & Hl II \\
\hline $220-224$ & 0.41 & 1.12 & 30.82 & 13.73 & 26.45 & 27.47 & 67.65 & 0.004 & 3.9 & - & - & Silty clay & HI II \\
\hline
\end{tabular}

Station $2293-3,43^{\circ} 11^{\prime} \mathrm{N}, 36^{\circ} 24^{\prime} \mathrm{E}$, depth 2153 meters

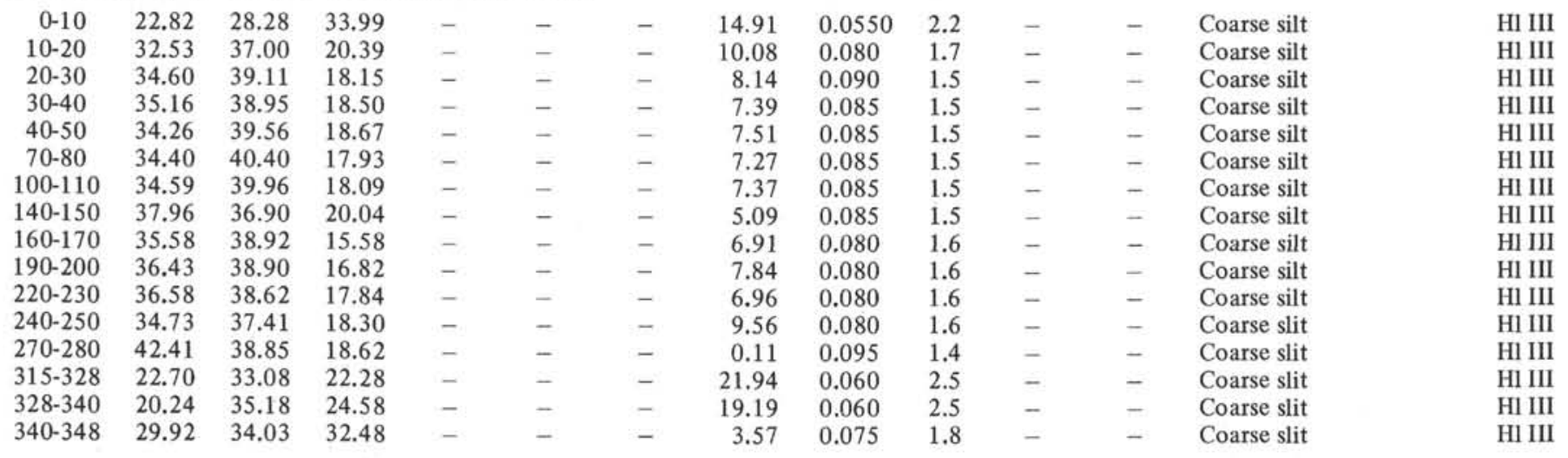

Station $4750-1,42^{\circ} 50^{\prime} \mathrm{N}, 37^{\circ} 34^{\prime} \mathrm{E}$, depth 2163 meters

\begin{tabular}{|c|c|c|c|c|c|c|c|c|c|c|c|c|c|}
\hline $0-3$ & 0.00 & 0.00 & 0.73 & 4.64 & 26.91 & 61.72 & 93.27 & 0.001 & - & - & - & Pelitic (nanno) ooze & $\mathrm{HI} \mathrm{III}$ \\
\hline $3-18$ & tr. & 0.24 & 19.28 & 17.35 & 18.31 & 44.81 & 80.42 & 0.0019 & - & - & - & Pelitic (nanno) ooze & HI III \\
\hline $0-3$ & tr. & 0.65 & 16.61 & 12.70 & 35.18 & 34.85 & 82.73 & 0.002 & 3.0 & 50.67 & 3.41 & Pelitic (nanno) ooze & $\mathrm{Hl} \mathrm{III}$ \\
\hline $3-8$ & 1.42 & 2.71 & 19.77 & 5.43 & 41.73 & 28.94 & 76.10 & 0.0025 & 3.1 & 56.86 & 5.23 & Pelitic (nanno) ooze & $\mathrm{Hl} \mathrm{III}$ \\
\hline $8-15$ & 1.72 & 3.54 & 22.75 & 16.48 & 32.15 & 23.36 & 71.99 & 0.0035 & 3.1 & 61.93 & 5.00 & Pelitic (nanno) ooze & HI III \\
\hline
\end{tabular}


TABLE 2 - Continued

\begin{tabular}{|c|c|c|c|c|c|c|c|c|c|c|c|c|c|}
\hline $\begin{array}{l}\text { Horizon } \\
(\mathrm{cm})\end{array}$ & $>0.1^{\mathrm{a}}$ & $\begin{array}{l}0.1- \\
0.05\end{array}$ & $\begin{array}{l}0.05- \\
0.01\end{array}$ & $\begin{array}{l}0.01- \\
0.005\end{array}$ & $\begin{array}{l}0.005- \\
0.001\end{array}$ & $<0.001$ & $<0.01$ & $(\mathrm{~mm})$ & So & $\underset{(\%)}{\mathrm{CaCO}_{3}}$ & $\begin{array}{l}\mathrm{C}_{o r g} \\
(\%)\end{array}$ & Type of Sediments & Age \\
\hline $15-25$ & 0.63 & 10.09 & 47.51 & 9.74 & 21.93 & 10.09 & 41.76 & 0.011 & 3.1 & 18.58 & 10.74 & Sapropelic fine silty mud & Hl III \\
\hline $55-70$ & 2.32 & 8.75 & 47.64 & 11.07 & 19.57 & 10.64 & 41.28 & 0.015 & 3.1 & 10.05 & 0.84 & Fine silty mud & HI II \\
\hline $70-80$ & 4.55 & 19.23 & 48.65 & 9.10 & 8.61 & 9.84 & 27.55 & 0.021 & 2.3 & 9.78 & 0.66 & Fine silty mud & $\mathrm{HI}$ II \\
\hline $80-93$ & 16.65 & 23.66 & 39.45 & 7.86 & 7.04 & 5.50 & 20.40 & 0.034 & 2.5 & 9.30 & 0.51 & Fine silty mud & $\mathrm{Hl}$ II \\
\hline $93-98$ & 18.01 & 44.75 & 16.90 & 14.30 & 5.66 & 0.37 & 20.33 & 0.06 & 2.4 & 11.12 & 0.50 & Coarse silt & $\mathrm{Hl}$ II \\
\hline $98-115$ & 7.29 & 38.00 & 38.92 & 0.66 & 6.83 & 8.28 & 15.77 & 0.043 & 2.0 & 3.30 & 1.90 & Fine silty mud & HI II \\
\hline $115-130$ & 3.19 & 2.76 & 44.14 & 16.87 & 11.03 & 21.98 & 49.88 & 0.010 & 4.0 & 14.19 & 1.93 & Fine silty mud & Hl II \\
\hline $130-145$ & 0.17 & 0.94 & 38.47 & 13.62 & 22.28 & 24.51 & 60.41 & 0.006 & 4.1 & 13.96 & 1.95 & Silty clay & HI II \\
\hline $145-160$ & 3.92 & 1.17 & 59.47 & 5.25 & 7.51 & 22.68 & 35.44 & 0.013 & 3.7 & 12.94 & 1.82 & Fine silty mud & Hl II \\
\hline $160-172$ & 1.24 & 1.24 & 51.57 & 9.23 & 12.84 & 23.88 & 45.95 & 0.012 & 3.5 & 13.62 & 1.92 & Fine silty mud & HI II \\
\hline $178-185$ & 14.68 & 40.47 & 23.25 & 6.99 & 5.83 & 8.78 & 21.60 & 0.053 & 2.8 & 14.49 & 1.31 & Coarse silt & HI II \\
\hline $185-198$ & 1.95 & 1.67 & 52.37 & 9.12 & 11.35 & 23.53 & 44.00 & 0.012 & 4.4 & 15.08 & 1.25 & Fine silty mud & Hl II \\
\hline $198-205$ & 0.46 & 1.83 & 68.58 & 11.05 & 8.81 & 9.26 & 29.12 & 0.016 & 1.9 & 10.69 & 0.32 & Fine silty mud & HI II \\
\hline $205-210$ & 0.00 & 6.13 & 28.16 & 14.52 & 21.44 & 29.74 & 65.70 & 0.0047 & 4.0 & 9.64 & 0.37 & Silty clay & Hl II \\
\hline $210-216$ & 53.97 & 21.39 & 9.56 & 5.29 & 3.35 & 6.45 & 15.09 & 0.12 & 2.0 & 8.66 & 0.36 & Fine-grained sand & HI II \\
\hline $216-224$ & 4.26 & 3.69 & 35.74 & 17.05 & 21.47 & 17.79 & 56.31 & 0.007 & 2.9 & 13.92 & 0.81 & Silty clay & $\mathrm{Hl}$ II \\
\hline $224-234$ & 6.91 & 40.41 & 28.70 & 8.85 & 9.50 & 5.90 & 24.25 & 0.047 & 2.5 & 11.37 & 0.53 & Coarse silt & Hl II \\
\hline $234-243$ & 6.93 & 36.55 & 24.20 & 3.15 & 8.18 & 14.98 & 32.31 & 0.040 & 3.5 & 11.14 & 0.59 & Coarse silt & HI II \\
\hline $243-248$ & 25.09 & 51.25 & 12.43 & 4.28 & 2.02 & 4.93 & 11.23 & 0.075 & 1.4 & 17.92 & 0.78 & Coarse silt & HI II \\
\hline
\end{tabular}

Station $4750-3,42^{\circ} 48.9^{\prime} \mathrm{N}, 37^{\circ} 31.7^{\prime} \mathrm{E}$, depth 2166 meters

\begin{tabular}{|c|c|c|c|c|c|c|c|c|c|c|c|c|c|}
\hline $0-33$ & 3.76 & 18.43 & 45.97 & 11.09 & 9.12 & 11.62 & 31.83 & 0.020 & 2.6 & 11.87 & - & Fine silty mud & Hl III \\
\hline $51-65$ & tr. & 3.71 & 30.80 & 12.28 & 19.49 & 33.72 & 65.49 & 0.0038 & 5.6 & 13.05 & - & Silty clay & $\mathrm{Hl} \mathrm{II}$ \\
\hline $65-80$ & 0.17 & 1.82 & 46.57 & 12.77 & 25.19 & 13.47 & 51.43 & 0.0085 & 3.0 & - & - & Fine silty mud & Hl II \\
\hline 80-101 & 0.58 & 2.02 & 48.51 & 14.60 & 20.08 & 14.22 & 48.90 & 0.010 & 2.7 & - & - & Fine silty mud & HI II \\
\hline $123-127$ & 8.40 & 41.54 & 19.18 & - & - & - & 30.88 & 0.048 & 4.7 & 11.39 & - & Coarse silt & $\mathrm{Hl}$ II \\
\hline $131-136$ & 57.17 & 20.31 & 11.04 & - & - & - & - & 0.12 & 1.7 & - & - & Fine-grained sand & Hl II \\
\hline $145-151$ & 1.98 & 2.80 & 20.36 & 11.13 & 29.27 & 34.46 & 74.86 & 0.0026 & 3.0 & - & - & Clay & Hl II \\
\hline $151-168$ & 7.98 & 41.41 & 25.17 & - & - & - & 25.44 & 0.049 & 2.8 & 11.03 & 0.52 & Coarse silt & HI II \\
\hline $168-185$ & 25.10 & 52.04 & 11.69 & - & - & - & 11.17 & 0.075 & 1.4 & - & - & Coarse silt & $\mathrm{Hl}$ II \\
\hline $185-208$ & 35.18 & 37.61 & 23.04 & 0.00 & 2.49 & 1.68 & 4.17 & 0.042 & 1.7 & - & - & Coarse silt & HI II \\
\hline $208-220$ & 59.96 & 24.22 & 12.51 & 0.30 & 2.12 & 0.89 & - & 0.12 & 1.8 & - & - & Fine-grained sand & $\mathrm{HI} \mathrm{II}$ \\
\hline $220-234$ & 53.60 & 31.64 & 7.55 & - & - & - & 7.21 & 0.11 & 1.7 & - & - & Fine-grained sand & Hl II \\
\hline $234-254$ & 5.23 & 4.28 & 46.27 & 13.02 & 20.14 & 11.05 & 44.21 & 0.012 & 2.8 & 10.51 & 0.76 & Fine silty mud & HI II \\
\hline $254-269$ & 1.52 & 19.54 & 32.36 & 10.81 & 15.52 & 20.24 & 46.57 & 0.013 & 5.2 & 10.80 & 0.76 & Fine silty mud & Hl II \\
\hline $269-273$ & 60.46 & 21.66 & 11.81 & 2.63 & 0.40 & 3.04 & 6.07 & 0.13 & 1.8 & - & - & Fine-grained sand & $\mathrm{HI}$ II \\
\hline $279-389$ & 9.27 & 64.03 & 13.35 & - & - & - & 13.36 & 0.067 & 1.4 & - & - & Coarse silt & HI II \\
\hline $289-399$ & 59.18 & 21.98 & 13.56 & 0.19 & 2.66 & 2.42 & 5.27 & - & - & - & - & Fine-grained sand & HI II \\
\hline $299-313$ & 54.50 & 28.44 & 8.65 & - & - & - & 8.41 & 0.11 & 1.7 & 10.32 & - & Fine-grained sand & HI II \\
\hline $334-340$ & 30.04 & 21.09 & 26.80 & 3.87 & 10.46 & 7.74 & 22.07 & 0.053 & 3.5 & 10.76 & 0.40 & Coarse silt & $\mathrm{Hl} \mathrm{I}$ \\
\hline $345-352$ & 0.88 & 0.22 & 11.55 & 8.91 & 38.28 & 40.15 & 87.34 & 0.002 & 2.3 & 6.03 & 1.24 & Clay & $\mathrm{HI} \mathrm{I}$ \\
\hline $367-382$ & 2.71 & 15.04 & 43.99 & 9.19 & 18.38 & 10.69 & 38.26 & - & - & 13.71 & 1.09 & Fine silty mud & Hl I \\
\hline $390-402$ & 9.73 & 47.33 & 19.73 & - & - & - & 23.21 & 0.055 & 2.7 & 11.02 & 0.61 & Coarse silt & HI I \\
\hline $402-415$ & 17.61 & 29.50 & 38.13 & 3.83 & 9.29 & , 1.63 & - & 0.045 & 2.1 & - & - & Fine silty mud & $\mathrm{HI} \mathrm{I}$ \\
\hline $415-426$ & 14.36 & 49.47 & 18.75 & - & - & - & 17.42 & 0.061 & 2.0 & 11.01 & 0.22 & Coarse silt & Hl I \\
\hline $428-435$ & 36.84 & 38.18 & 13.09 & - & - & - & 11.89 & 0.080 & - & 10.82 & 0.24 & Coarse silt & $\mathrm{Hl} \mathrm{I}$ \\
\hline $435-451$ & 52.29 & 21.62 & 20.17 & 0.77 & 2.84 & 2.31 & 5.92 & - & - & 10.51 & 0.18 & Fine-grained sand & HI I \\
\hline $451-468$ & 52.20 & 26.69 & 19.82 & 0.15 & 0.94 & 0.20 & 1.29 & - & - & - & - & Fine-grained sand & H1 I \\
\hline $468-480$ & 58.18 & 20.94 & 16.20 & 2.00 & 0.00 & 2.67 & 4.67 & - & - & - & - & Fine-grained sand & $\mathrm{HI} \mathrm{I}$ \\
\hline $480-495$ & 47.32 & 36.86 & 8.95 & - & - & - & 6.87 & - & - & 9.50 & - & Fine-grained sand & $\mathrm{HI} \mathrm{I}$ \\
\hline $495-500$ & 0.73 & 1.58 & 37.36 & 13.79 & 27.63 & 18.91 & 60.33 & 0.006 & 3.4 & - & - & Silty clay & $\mathrm{Hl} \mathrm{I}$ \\
\hline $500-507$ & 0.22 & 2.32 & 17.88 & 11.70 & 23.29 & 44.59 & 79.48 & 0.0015 & 4.8 & - & - & Clay : & $\mathrm{Hl} \mathrm{I}$ \\
\hline $507-515$ & 8.62 & 39.79 & 42.92 & 1.20 & 3.37 & 4.09 & 8.66 & 0.049 & 2.0 & 13.03 & 0.71 & Fine silty mud & $\mathrm{HII}$ \\
\hline $515-521$ & 20.88 & 36.03 & 30.41 & 2.62 & 4.50 & 5.56 & 12.68 & 0.022 & 2.0 & - & - & Fine silty mud & $\mathrm{Hl} \mathrm{I}$ \\
\hline $579-593$ & 13.15 & 26.21 & 14.80 & 8.90 & 17.21 & 19.73 & 45.84 & 0.014 & 0.3 & - & - & Fine silty mud & $\mathrm{Hl} \mathrm{I}$ \\
\hline $593-610$ & 26.41 & 23.61 & 38.54 & 8.18 & 3.26 & 0.00 & 11.44 & 0.020 & 2.3 & 11.30 & 0.49 & Fine silty mud & $\mathrm{Hl} \mathrm{I}$ \\
\hline $610-624$ & 40.41 & 26.10 & 24.89 & 1.36 & 4.09 & 3.14 & 8.59 & 0.098 & 1.7 & - & - & Coarse silt & HI I \\
\hline $624-646$ & 47.45 & 31.63 & 11.21 & - & - & - & 9,71 & 0.094 & - & 9.03 & - & Fine-grained sand & HI I \\
\hline $646-653$ & 28.49 & 23.48 & 11.61 & 5.35 & 14.12 & 16.96 & 36.43 & 0.053 & 7.3 & 11.87 & 0.42 & Coarse silt & $\mathrm{Hl} \mathrm{I}$ \\
\hline $653-677$ & 29.54 & 34.61 & 22.63 & - & - & - & 13.28 & 0.068 & 2.5 & 9.51 & 0.26 & Coarse silt & W II \\
\hline $677-700$ & 37.97 & 32.77 & 22.36 & tr. & 1.89 & 5.00 & 6.89 & 0.090 & 1.8 & - & - & Coarse silt & W II \\
\hline $700-720$ & 59.35 & 21.44 & 13.27 & 1.47 & 1.47 & 3.00 & 5.94 & 0.17 & 1.6 & - & - & Fine-grained sand & W II \\
\hline $740-760$ & 63.28 & 19.20 & 12.67 & 0.00 & 0.00 & 0.00 & 0.00 & - & - & - & - & Fine-grained sand & W II \\
\hline $760-785$ & 73.83 & 12.65 & 9.28 & 0.00 & 2.49 & 3.18 & 5.67 & - & - & - & - & Fine-grained sand & W II \\
\hline $785-805$ & 73.25 & 13.53 & 8.13 & tr. & 0.26 & 4.81 & 5.07 & 0.19 & 1.6 & 7.23 & - & Fine-grained sand & W II \\
\hline $805-830$ & 77.58 & 10.02 & 7.91 & 0.00 & 2.86 & 2.24 & 5.10 & - & - & - & - & Fine-grained sand & W II \\
\hline $830-850$ & 75.06 & 12.74 & 7.73 & 4.11 & - & - & - & - & - & - & - & & \\
\hline $870-890$ & 70.58 & 14.78 & 8.94 & 1.30 & tr. & 4.40 & 5.70 & 0.15 & 1.5 & - & - & Fine-grained sand & W II \\
\hline $890-913$ & 67.97 & 16.69 & 9.12 & tr. & 1.35 & 4.86 & 6.21 & 0.13 & 1.5 & 7.91 & 0.13 & Fine-grained sand & W II \\
\hline $913-930$ & 71.28 & 13.71 & 9.14 & 5.86 & tr. & tr. & 5.86 & 0.15 & 1.6 & - & - & Fine-grained sand & W II \\
\hline $930-940$ & 73.09 & 12.03 & 9.38 & 0.00 & 2.72 & 2.78 & 5.50 & - & - & - & - & Fine-grained sand & W II \\
\hline
\end{tabular}


TABLE 2 - Continued

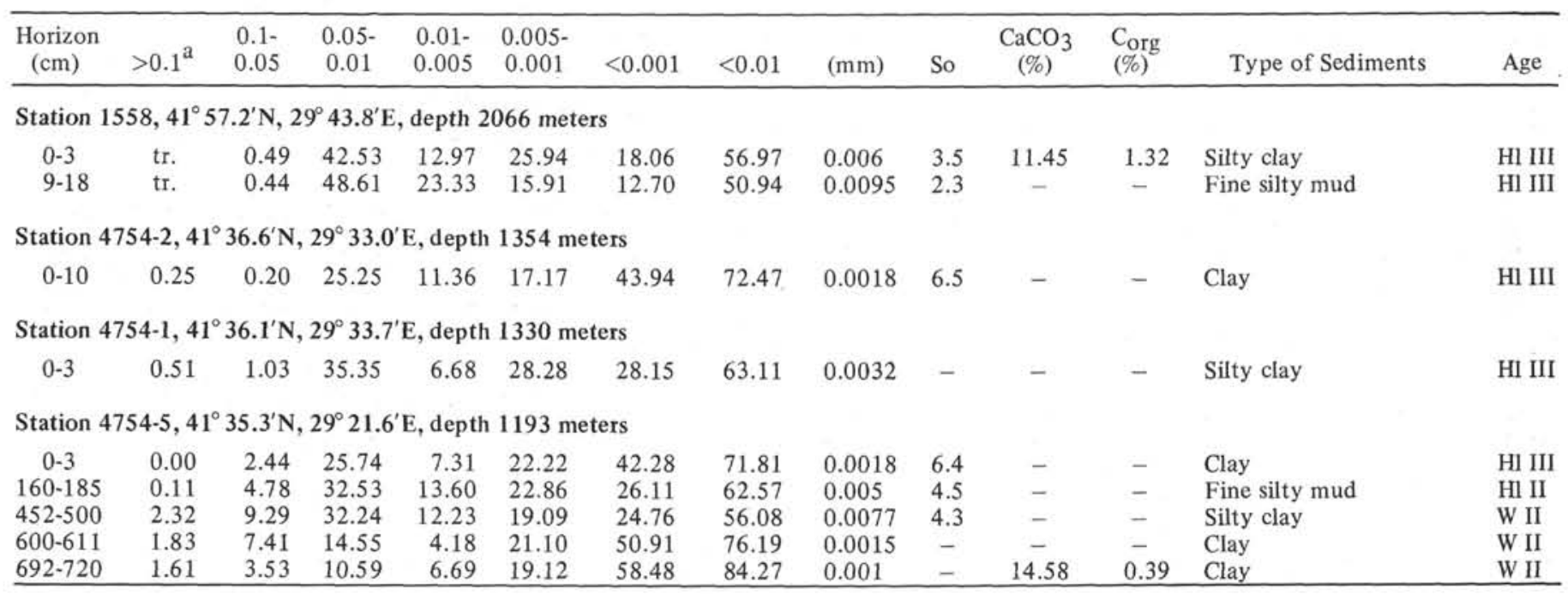

TABLE 3

Grain-Size Results, Hole 379A, Leg 42B

\begin{tabular}{|c|c|c|c|c|c|c|c|c|}
\hline \multirow{2}{*}{$\begin{array}{l}\text { Sample } \\
\text { (Interval } \\
\text { in } \mathrm{cm} \text { ) }\end{array}$} & \multicolumn{6}{|c|}{ Diameter of Particles (mm) } & \multirow[b]{2}{*}{$\begin{array}{c}\mathrm{Md} \\
(\mathrm{mm})\end{array}$} & \multirow[b]{2}{*}{ So } \\
\hline & $>0.1$ & $\begin{array}{l}0.1- \\
0.05\end{array}$ & $\begin{array}{l}0.05- \\
0.01\end{array}$ & $\begin{array}{l}0.01- \\
0.005\end{array}$ & $\begin{array}{l}0.005- \\
0.001\end{array}$ & $<0.001$ & & \\
\hline $1-2,70-78$ & 0.22 & 0.29 & 22.94 & 19.16 & 27.31 & 30.08 & 0.0032 & 3.9 \\
\hline $4-3,30-40$ & 0.48 & 1.24 & 20.30 & 19.50 & 33.80 & 24.67 & 0.0031 & 3.0 \\
\hline $4-5,125$ & 52.37 & 19.64 & 18.64 & 2.37 & 4.63 & 2.37 & 0.1100 & 2.2 \\
\hline $6-2,32-38$ & 2.04 & 2.04 & 27.52 & 15.21 & 32.91 & 20.28 & 0.0045 & 3.4 \\
\hline $6-5,36-46$ & 6.76 & 30.97 & 38.02 & 6.38 & 10.20 & 7.68 & 0.0460 & 2.1 \\
\hline $6-6,0-2$ & tr. & 1.08 & 40.91 & 18.42 & 23.73 & 15.85 & 0.0075 & 3.1 \\
\hline $7-2,20-30$ & 0.63 & 1.47 & 18.88 & 14.64 & 32.19 & 32.19 & 0.0025 & 4.5 \\
\hline $8-4,4-16$ & 1.58 & 4.32 & $2 ? .53$ & 16.07 & 27.53 & 22.97 & 0.0045 & 3.6 \\
\hline $9-3,100-108$ & 1.78 & 3.20 & 30.65 & 26.72 & 33.04 & 4.71 & 0.0070 & 2.4 \\
\hline $9-5,50-58$ & 8.42 & 9.95 & 40.78 & 14.05 & 19.74 & 7.05 & 0.0130 & 3.0 \\
\hline $10-1,120-130$ & 7.15 & 9.75 & 30.23 & 10.60 & 26.40 & 15.86 & 0.0085 & 4.5 \\
\hline $10-3,85-93$ & $32.93^{\mathrm{a}}$ & 24.17 & 27.70 & 4.75 & 6.65 & 3.81 & 0.0580 & 2.6 \\
\hline $10-5,11-13$ & 3.23 & 7.38 & 28.90 & 24.21 & 26.22 & 10.06 & 0.0070 & 2.6 \\
\hline $11-2,55-65$ & 2.17 & 15.20 & 36.37 & 13.04 & 24.93 & 8.30 & 0.0110 & 3.6 \\
\hline $11-5,77-78$ & 17.42 & 29.41 & 32.80 & 4.98 & 10.18 & 5.20 & 0.0450 & 2.4 \\
\hline $12-3,65-72$ & 0.13 & 0.19 & 16.50 & 14.94 & 31.97 & 36.26 & 0.0020 & 4.0 \\
\hline $12-3,120-130$ & 0.05 & 0.46 & 24.16 & 18.83 & 27.51 & 28.99 & 0.0032 & 3.8 \\
\hline $13-5,1-7$ & 3.91 & 4.41 & 27.90 & 9.82 & 29.41 & 24.55 & 0.0042 & 4.5 \\
\hline $14-2,80-82$ & 0.19 & 1.68 & 24.67 & 11.46 & 29.84 & 32.15 & 0.0024 & 4.0 \\
\hline $14-4,0-10$ & 3.83 & 1.98 & 32.53 & 18.15 & 23.58 & 19.94 & 0.0060 & 3.4 \\
\hline $15-2,55-65$ & 14.66 & 23.00 & 28.65 & 5.61 & 13.09 & 14.98 & 0.0290 & 4.5 \\
\hline $15-5,2-12$ & 2.81 & 2.54 & 18.19 & 19.15 & 33.42 & 23.88 & 0.0032 & 3.1 \\
\hline $16-2,50-52$ & 51.72 & 13.69 & 9.46 & 7.21 & 7.14 & 10.78 & 0.1200 & 5.5 \\
\hline $16-3,17-27$ & 18.37 & 5.92 & 20.87 & 9.12 & 32.01 & 13.70 & 0.0070 & 5.8 \\
\hline $17-1,25-35$ & 2.31 & 6.38 & 38.31 & 16.65 & 22.74 & 13.61 & 0.0090 & 3.4 \\
\hline $18-2,133-135$ & 0.44 & 0.44 & 37.10 & 15.54 & 36.22 & 10.26 & 0.0060 & 3.1 \\
\hline $19-3,83-84$ & tr. & 0.19 & 22.08 & 14.15 & 42.45 & 21.13 & 0.0026 & 2.9 \\
\hline $19-3,84-85$ & 0.21 & 2.06 & 60.91 & 11.01 & 18.41 & 7.41 & 0.0150 & 2.3 \\
\hline $19-3,85-96$ & 0.06 & 0.19 & 13.18 & 19.81 & 42.04 & 24.71 & 0.0025 & 2.6 \\
\hline $19-3,96-98$ & 0.15 & 0.31 & 26.08 & 14.23 & 28.46 & 30.77 & 0.0027 & 3.8 \\
\hline $19-6,9-21$ & 0.29 & 0.65 & 33.98 & 17.70 & 25.66 & 21.71 & 0.0052 & 2.7 \\
\hline $19-6,128-130$ & tr. & 0.08 & 29.40 & 20.94 & 28.73 & 2085 & 0.0048 & 3.0 \\
\hline $19-6,132-134$ & 0.14 & 10.75 & 60.50 & 9.56 & 9.56 & 9.49 & 0.0170 & 2.0 \\
\hline $20-3,23-25$ & $34.56^{\mathrm{a}}$ & 23.80 & 27.20 & 3.68 & 3.69 & 7.08 & 0.0600 & 2.8 \\
\hline $21-4,0-10$ & 0.07 & 0.07 & 21.23 & 24.60 & 31.95 & 22.09 & 0.0042 & 2.8 \\
\hline $21-6,0-10$ & 0.12 & 2.43 & 27.99 & 19.51 & 19.58 & 30.36 & 0.0046 & 4.6 \\
\hline $22-4,47-55$ & 0.05 & 0.11 & 39.07 & 19.25 & 25.20 & 16.32 & 0.0069 & 3.0 \\
\hline $23-2,0-11$ & 0.03 & 0.19 & 11.68 & 19.19 & 46.30 & 22.61 & 0.0022 & 2.3 \\
\hline $23-2,150-152$ & $31.84^{\mathrm{a}}$ & 27.07 & 31.00 & 3.40 & 3.40 & 3.29 & 0.0600 & 2.2 \\
\hline $24-2,0-18$ & 0.12 & 0.30 & 22.15 & 20.96 & 29.28 & 27.20 & 0.0036 & 3.4 \\
\hline $24-4,133-135$ & tr. & 0.89 & 44.54 & 19.86 & 24.86 & 9.84 & 0.0090 & 2.4 \\
\hline $24-4,140-141$ & 0.36 & 4.32 & 59.35 & 12.23 & 11.87 & 11.87 & 0.0150 & 2.4 \\
\hline $24-6,62-74$ & 0.03 & 0.56 & 28.52 & 51.33 & 17.10 & 2.46 & 0.0070 & 1.5 \\
\hline
\end{tabular}


TABLE 3-Continued

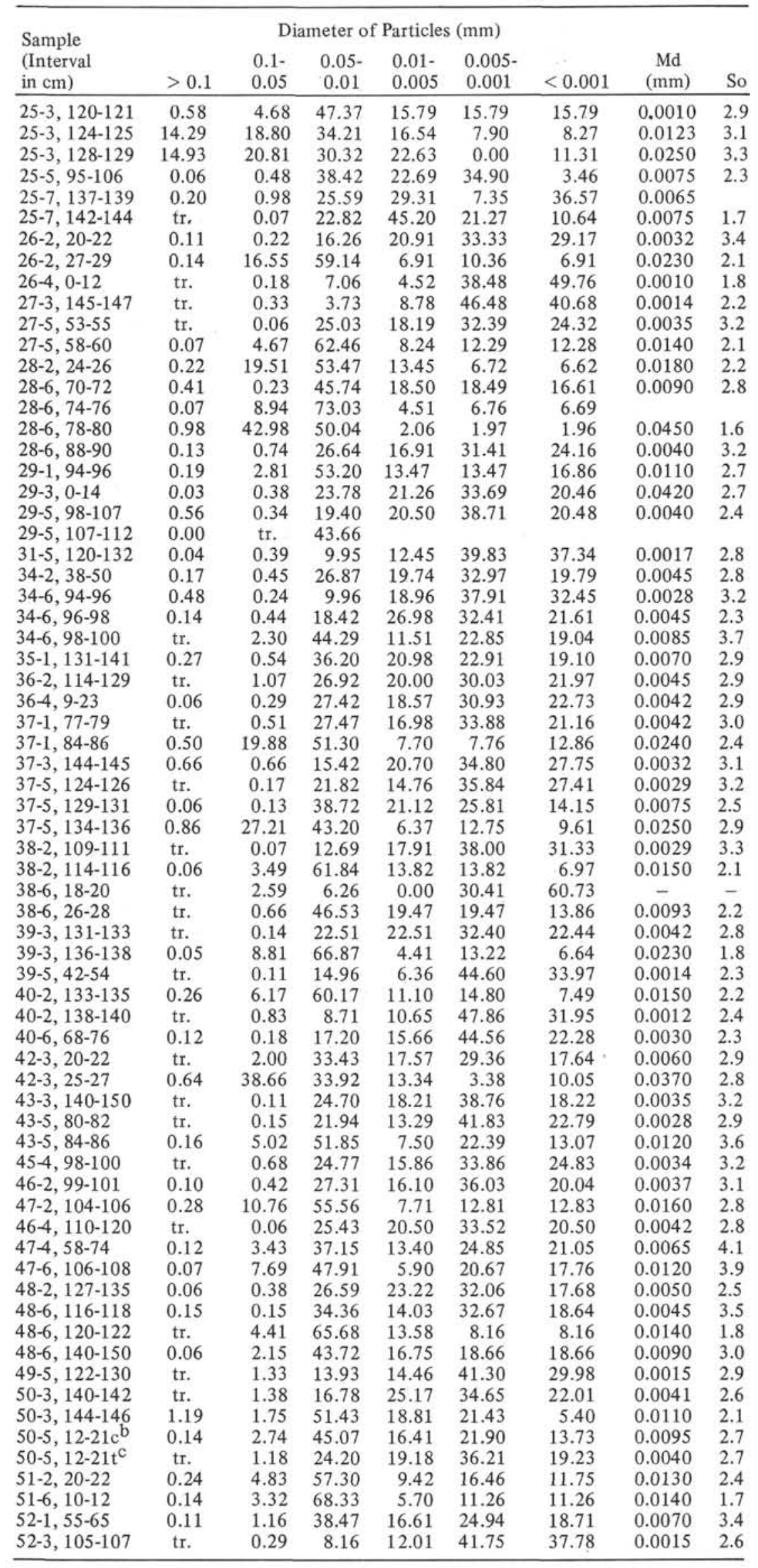


TABLE 3 - Continued

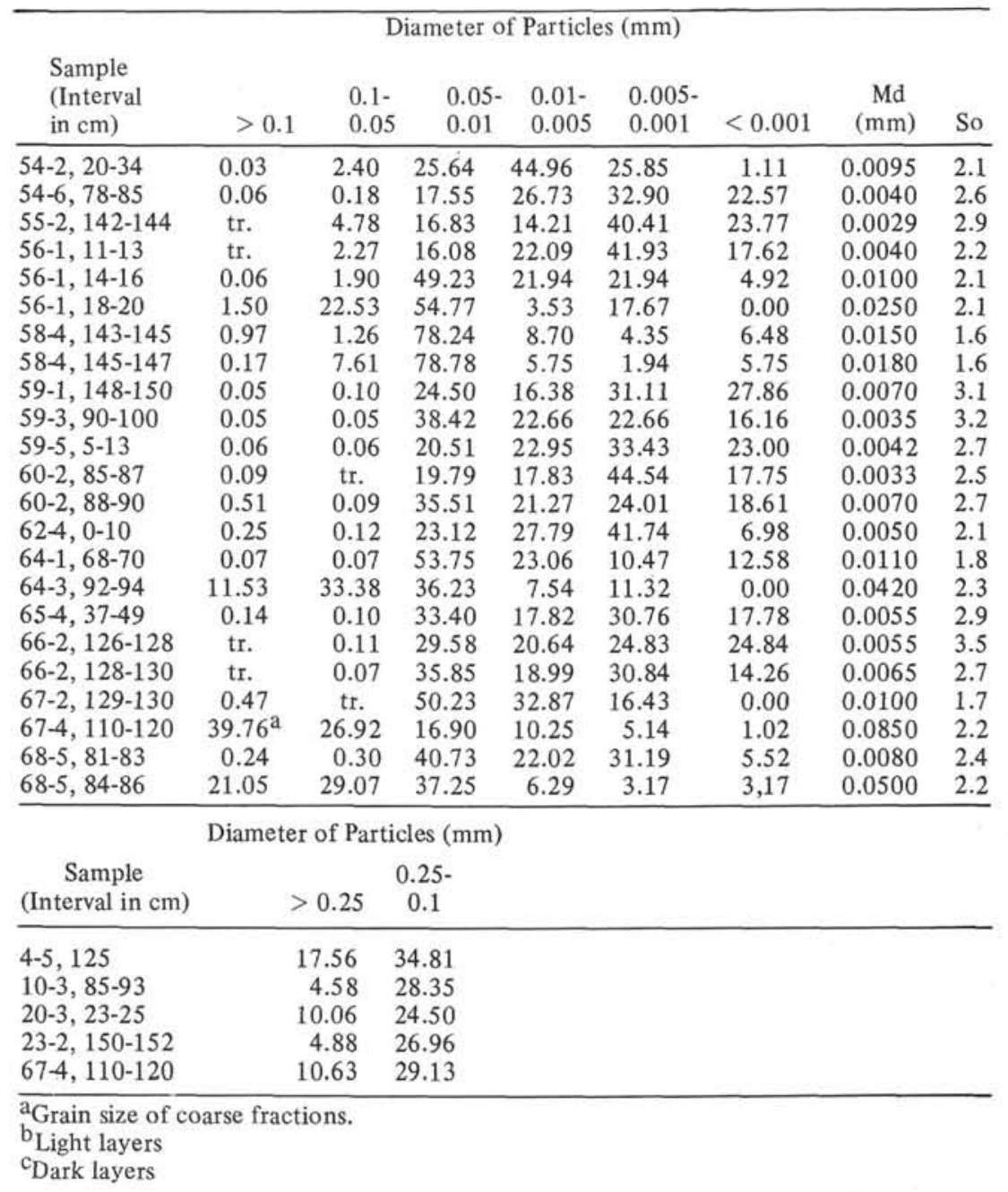

In aleurite-pelitic and fine silty muds, the fine aleuritic fraction is usually predominant. Its content is particularly high in well-sorted, fine silty muds (Table 3 ).

Size-graded rhythms are found in the Mindel sequence. Two rhythms consisting of fine silty and aleurite-pelitic muds appear in Sample 48-6, 116-150 cm, and similar rhythms occur in Sample 42-3, 20-27 cm. In Sample 46-2, 99-106 cm the rhythm contains fine silty mud which changes to pelite within one centimeter. Similar rhythms are found in Samples $43-5,80-86 \mathrm{~cm}, 39-3,131-138 \mathrm{~cm}, 38-2,109-116 \mathrm{~cm}$, and $37-5,124-136 \mathrm{~cm}$. In Samples 34-6, 94-98 cm, and 38-6, $18-28 \mathrm{~cm}$, the Md decreases upwards from 0.0045 to 0.0028 $\mathrm{mm}$, relative to the gradual increase of finely dispersed material in the pelitic muds.

The same granulometric types, as in the overlying beds, occur in Gunz-Mindel deposits (Unit 9). Pelitic muds (including finely dispersed ones) are characterized by the medium-pelitic fraction abundance. Sometimes these fractions make up more than 40 per cent (Samples 52-3, 105-107 $\mathrm{cm}, 55-2,142-144 \mathrm{~cm}, 56-1,11-13 \mathrm{~cm}, 60-2,85-87 \mathrm{~cm}$, $62-4,0-10 \mathrm{~cm})$. In aleurite-pelitic and fine-silty muds the fine aleuritic fraction prevails but in coarse silts the sandy, coarse aleuritic and fine aleuritic fractions dominate (Samples 67-4, $110-120 \mathrm{~cm}, 68-5,84-86 \mathrm{~cm}$ ).
As in foregoing units, graded rhythms consisting of coarse and fine silts (Core 68, Section 5), fine silty muds of different dispersion degrees (Core 58, Section 4), fine silty muds changing to pelitic muds (Cores 50, Section 3 and 56, Section 1) and aleurite-pelitic muds changing into pelitic ones (Core 60, Section 2 and Core 66, Section 2) are found here.

Considering the grain-size composition of Hole 379A deposits, the appreciable variability is noteworthy, indicating that sedimentation conditions were unsteady and changed repeatedly during some of the Pleistocene stages.

Units corresponding to glacial stages (Units 3, 6, 8), consisting basically of clay, silty clay and muds, are enriched mainly in well-sorted, sandy silt interbeds, fine-grained sands, coarse and fine silts. These sediments are characterized by the widespread occurrence of turbidites containing not only sands and silts, but also muds and clays.

In Würm sediments, turbidites are observed mainly in the upper part of the sequence; in the Riss they are in the lower (Cores 23 and 24), middle (Cores 19-20), and upper (Cores 12-13) parts; in Mindel sediments, turbidites are distributed almost uniformly throughout the strata forming essentially the bulk of it. This feature is reflected in changing median diameters, the largest limit values of which correspond to the Würm and Riss stages. 


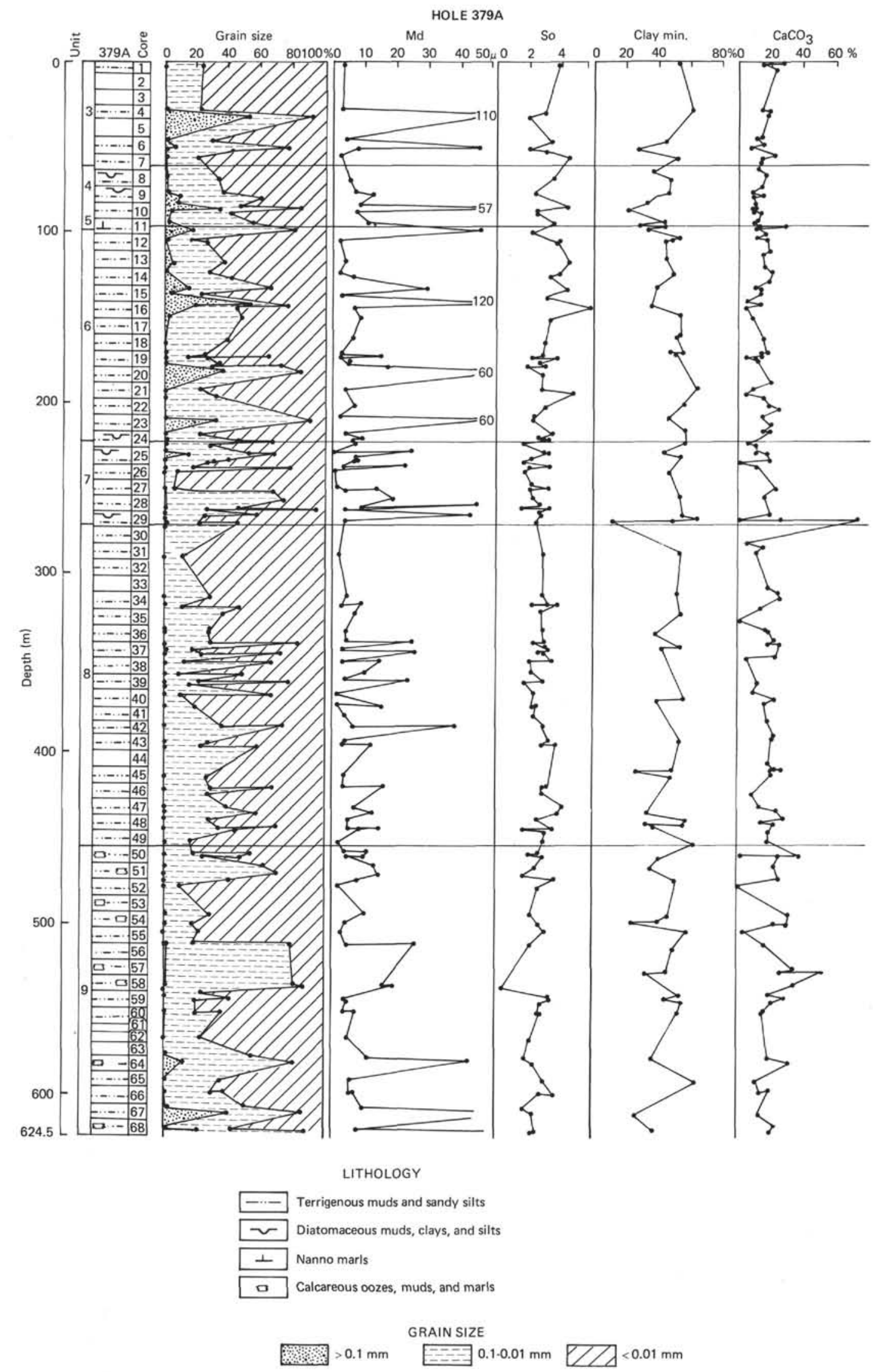

Figure 2. Grain-size fractions, Md and So, Hole 379A. 
The interbeds of finely dispersed pelitic muds that are encountered in different parts of the units suggest short periods of quiet sedimentation when turbidity currents did not penetrate into the site area.

Units corresponding to interglacial stages, as well as the Holocene sediments, differ slightly from glacial units as to the grain-size composition. In addition to clay and silty clay, fine silty muds and coarse silts are extensive. Interbeds of fine-grained sands also occur. Turbidites, most commonly consisting of fine silty material, are present. Coarse silts and fine-grained sands are less common in the turbidites. Rare interbeds of finely dispersed muds are found in Mindel-Riss sediments, and rare interlayers with anomalously high contents of coarse pelitic material (45.20\%-51.33\%) occur at the top of Mindel-Riss and Gunz-Mindel (44.96\%) sequences.

\section{HOLES 380/380A}

Recent sediments of this region are represented by low calcareous pelitic and aleurite-pelitic muds (Shimkus and Trimonis, 1974) (see Station 1558, Table 2). The Holocene section is basically formed of sediments in Holes 380/380A interbeds of finely dispersed terrigenous muds, sapropelic clays, and nannofossil oozes. The grain-size composition of Holes 380/380A sediments is given in Tables 4 and 5 and in Figures 4-7.

The Würm terrigenous deposits marking the top of the site (Unit B-1-c, Figure 4) are characterized by rather variable Md values. Terrigenous and shelly coarse-grained sediments, such as sands and silts constituting some interbeds in Cores 1 and 2, play a considerable role in the strata among prevalent aleurite-pelitic and pelitic muds. Sediment sorting becomes poorer in some places because of shelly detritus accumulation.

In pelitic muds the medium pelitic and subcolloidal fractions are of primary importance; in addition to that, the fine aleuritic fraction dominates over aleurite-pelitic ones. The grain-size composition of the layers studied indicates that most of them are constituents of turbidites.

In the Riss-Würm sequence (Unit B-1-d) pelitic, aleuritepelitic, and fine silty muds are the main components. Sandy silt interbeds rarely are present here. There are very thin $(\mathrm{mm})$ microlayers in aleurite-pelitic and fine silty muds, consisting of quartz, feldspars, carbonates, and micas probably of eolian origin. The scattered sandy silt material is represented by quartz, feldspars, diatom shells, pyrite, carbonates, etc.

Riss deposits (Unit B-1-e) are mainly made of clay and terrigenous muds. In the grain-size profile of these sediments the subcolloidal fraction dominates most often, and the fine aleuritic one prevails rather rarely. Finely dispersed pelitic muds (Samples 10-4, 106-132 cm and 13-6, 4-12 cm) are characterized by the relatively high content of the coarse pelitic fraction. The grain-size composition change is quite gradual and cyclic.

Mindel-Riss sediments (Unit B-1-f) are mainly constituted of aleurite-pelitic and finely dispersed pelitic muds (Table 4). Sandy silt interbeds are met only in Core 18 , Section 6 . The transition of finely dispersed pelitic muds to aleurite-pelitic ones in the grain-size profile is usually reflected in a sharp increase of the fine aleuritic fraction content. It is most commonly linked with enriching in diatoms in some intervals.
Mindel deposits (Units B-1-g,h) are characterized by widespread terrigenous silt and sand layers with usual thicknesses of $10-20 \mathrm{~cm}$ or more. They are seen in Cores 19 (Section 6), 28 (Section 1), 29 (Section 2), 30 (Section 1), 31 (Sections 1 and 2), 32 (Sections 3, 4, and 6), 33 (Section 3) etc. The number of sandy silt interbeds increases in Unit B-1-h, the bulk of which is made of turbidites. In pelitic and especially in finely dispersed muds, the subcolloidal fraction prevails, and in the aleurite-pelites, in addition to this fraction, the contents of fine aleuritic and medium pelitic fractions are increased not infrequently. Very thin interbeds of light gray and greenish gray fine silt essentially consisting of quartz, feldspars, carbonates, and some mica occur in muds; probably, this material is of eolian origin.

The Eopleistocene (Menap, Waal, Eburon) sequence at Holes 380/380A is represented by Units B-2 and B-3 (Figures 4,6 ). The grain-size composition of these sediments is variable, although on the whole, the pelitic and aleurite-pelitic muds are predominant. Pelitic muds prevail in the upper part of the Eopleistocene strata. In their grain-size profile the subcolloidal fraction dominates most commonly (Tables 4 and 5, Figures 5 and 7). Md values are low and change slightly (Figures 4 and 6). The diatom accumulations increase the fine aleuritic fraction content at some intervals. In such cases very thin (mm part) interbeds of light gray fine silt are observed. The lower part of Unit B-2 (Cores 5-12) mainly contains clay and carbonate varves.

As for grain-size composition, carbonate varves (Samples 9-6, 97-106 cm, 12-4, 0-16 cm, 14-3, 15-28 cm, 17-2, 56-70 $\mathrm{cm}, 18-3,33-48 \mathrm{~cm}, 19-4,0-16 \mathrm{~cm}, 22-3,84-96 \mathrm{~cm}, 23-3$, $21-33 \mathrm{~cm}, 23-5,77-87 \mathrm{~cm}, 25-2,45-61 \mathrm{~cm}, 30-2,38-50 \mathrm{~cm})$ correspond to usual peltic $(\mathrm{Md}=<0.0039 \mathrm{~mm}$, So $=3.1$ 4.6) and aleurite-pelitic ( $\mathrm{Md}=0.0044-0.0081 \mathrm{~mm}$, So $=$ 2.5-4.7) muds. The content of the subcolloidal fraction is essentially decreased and the fine aleurites are increased in them. The latter mainly consists of irregular calcite grains. It should be mentioned that a number of very thin microlayers in carbonate varves is made of fine silt-size calcite.

Clay varves, by their grain-size composition, comprise finely dispersed pelitic muds. The grain-size profile of pelitic muds is variable (Figure 7). Predominant fractions in different layers are: medium pelitic, subcolloidal, and mediumpelitic and subcolloidal together. The amount of sandy and coarse silt material is negligible in all samples (some percentage or less), $\mathrm{Md}=0,0004-0.0030 \mathrm{~mm}$, So $=2.2-5.3$. An interbed of low siliceous diatomaceous clay $(17.2,111-123$ $\mathrm{cm}$ ) with $\mathrm{Md}=0.0011 \mathrm{~mm}$, So $=2.3$ also corresponds to finely dispersed pelitic muds. Very thin microlayers $(\mathrm{mm})$ of fine silt almost entirely made of irregular calcite grains occur in them.

The layers of sandy silts (turbidites) with the thickness of about 10 to $40 \mathrm{~cm}$ are most commonly present in Cores 5-11, whereas thin silt interbeds are developed throughout the Eopleistocene section. Slump blocks of carbonate varves are found in Cores 17, 19, 21, 22, 25, 26, 27, 29, 30, 31, 32, and 33.

Clay varves occur as thinly laminated and consolidated clays, often with noticeable admixture of diatomaceous and organic matter. They prevail in the upper part of Pliocene section (Cores 35-38). Carbonate varves, siderites, and low siliceous diatomaceous muds form only rare interbeds. Diatomaceous varves, namely thinly laminated aleurite- 
HOLE 379A

UNIT 3
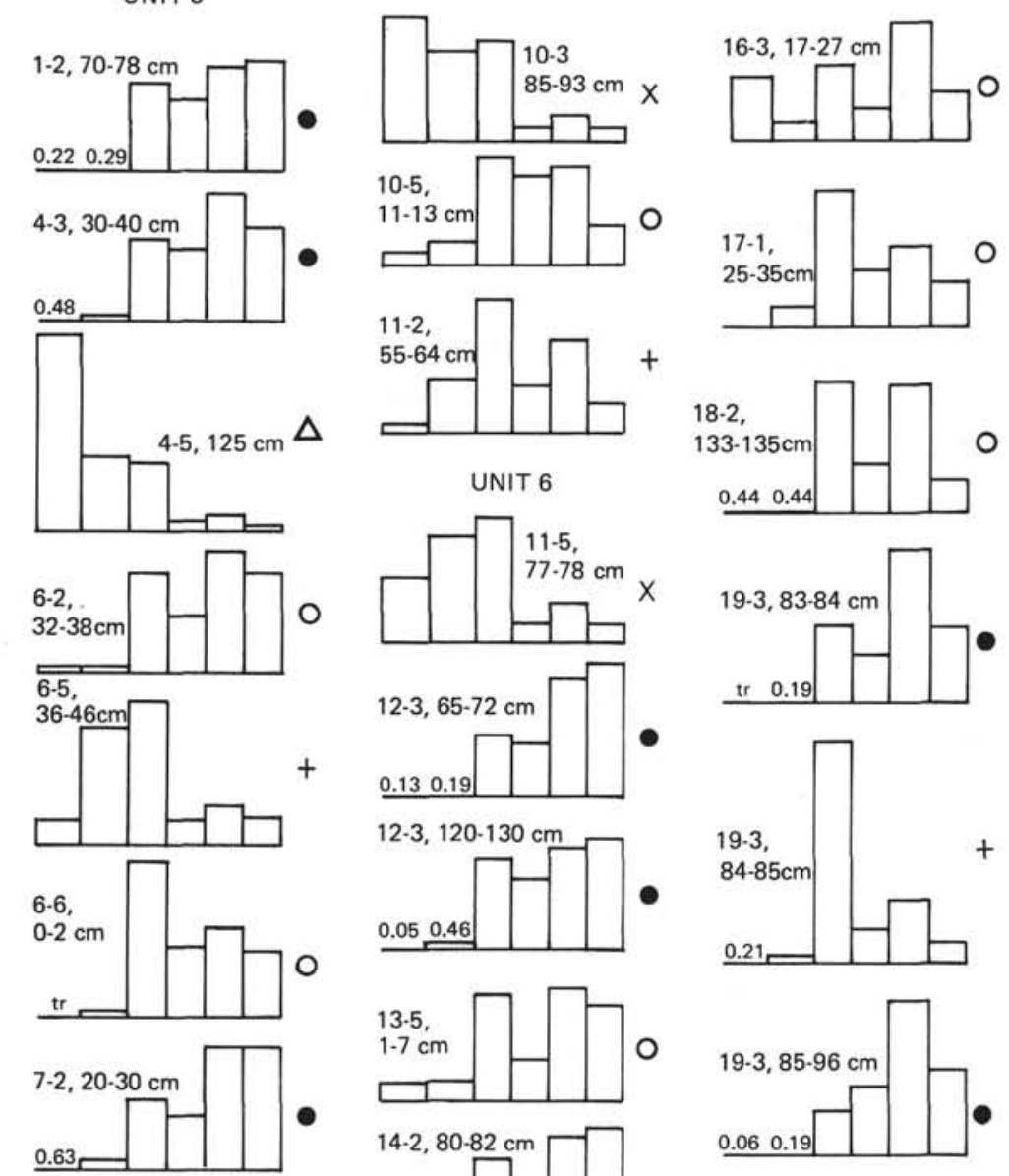

UNIT 4
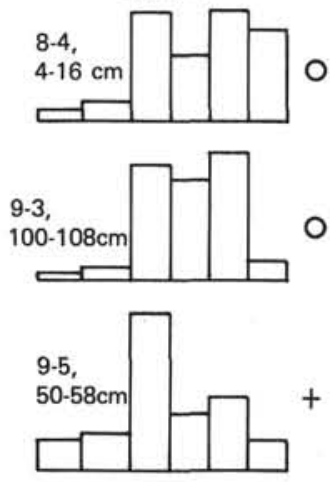

10-1,

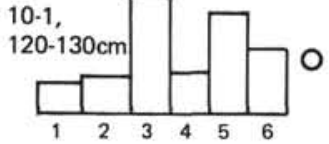

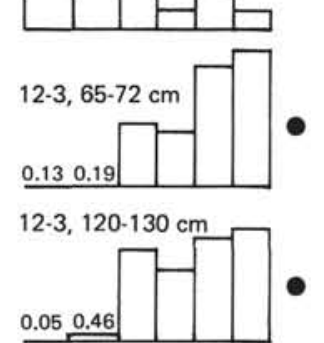
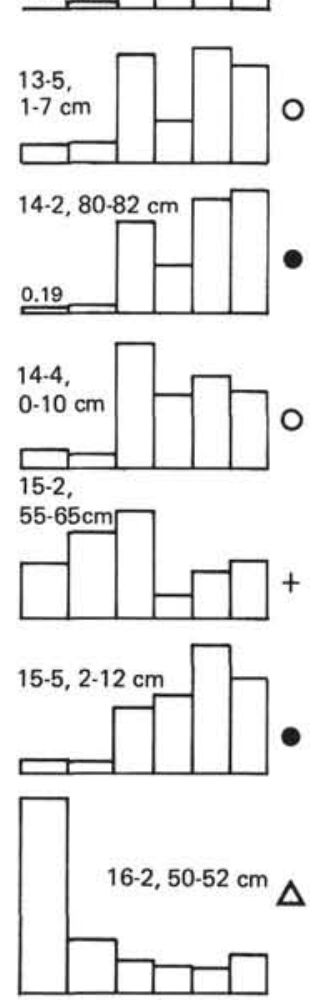
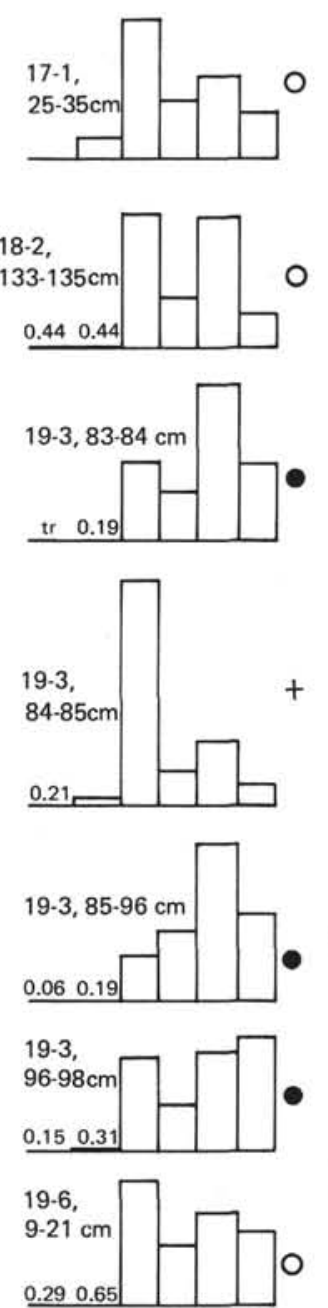

0.290 .65

$19-6$
$128-130$
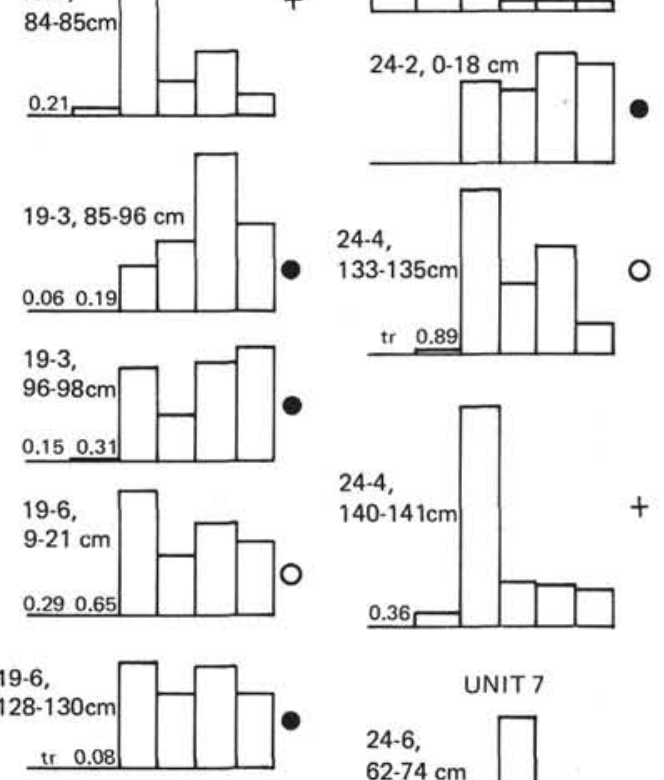

$132-134 \mathrm{~cm}$

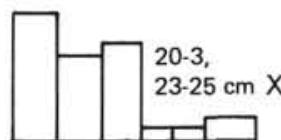

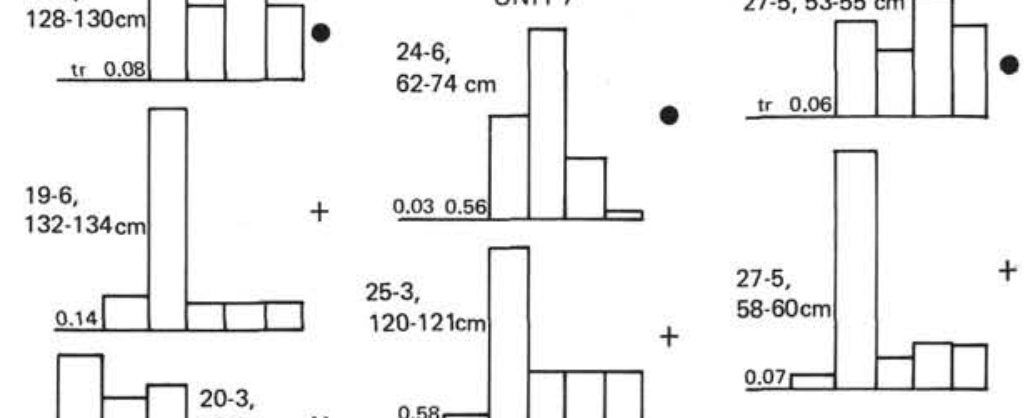

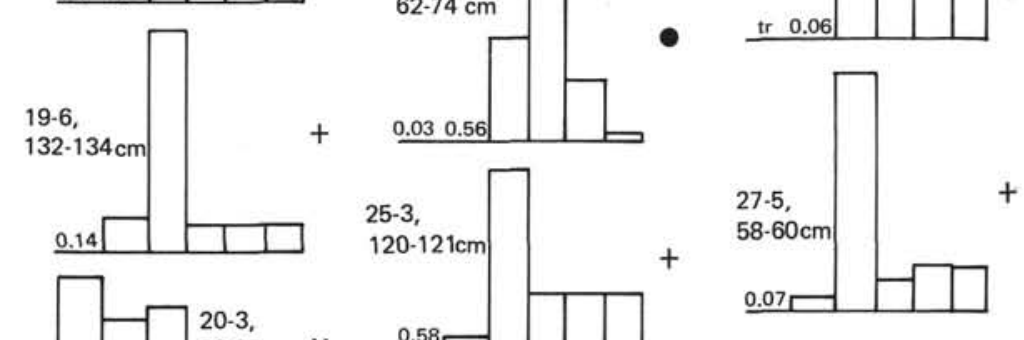

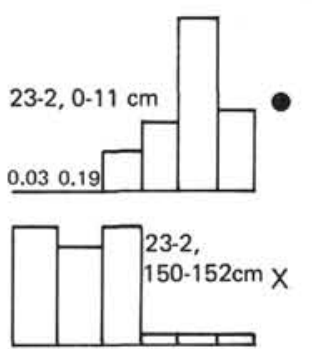

UNIT 7

$0.07 \quad 0.07$
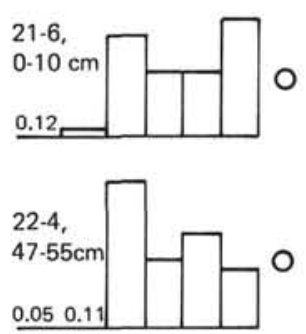

25-7,

$142-144 \mathrm{~cm}$
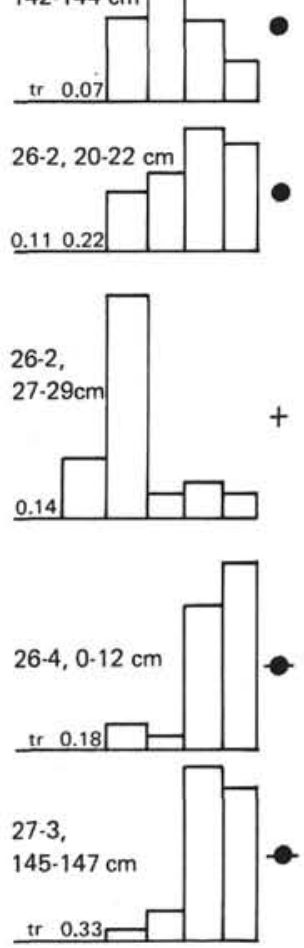

$27-5,53-55 \mathrm{~cm}$

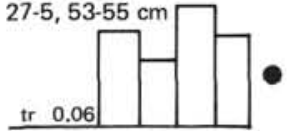

Figure 3. Grain-size histograms of Hole $379 \mathrm{~A}$ sediments: $1=$ sands, $2=$ coarse silts, $3=$ fine silty muds, $4=$ silty clay (aleurite-pelitic muds), 5 = clays (pelitic muds), 6 - finely dispersed pelitic muds. 


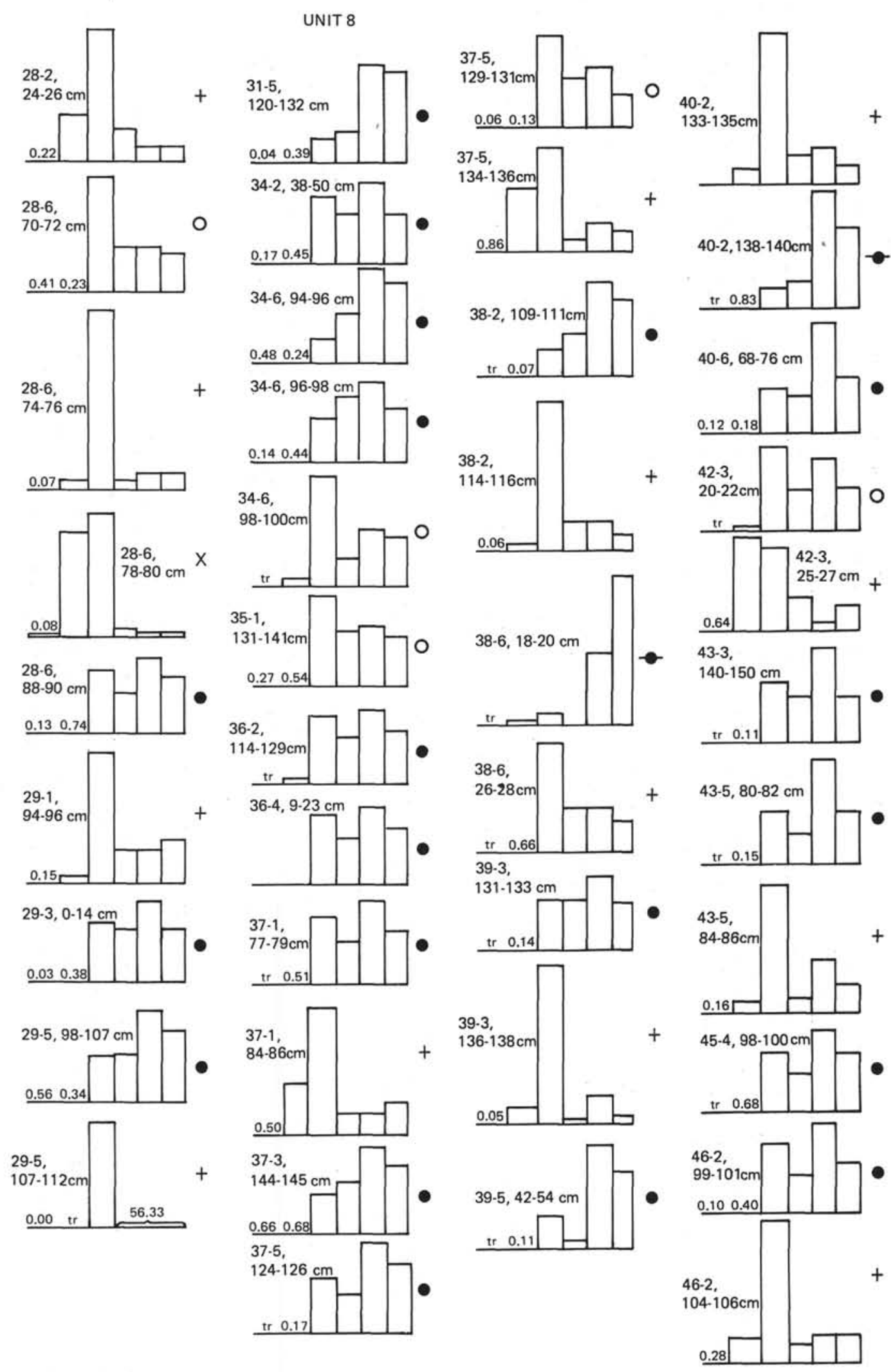

Figure 3c. Continued.

pelitic muds interbedded with clays and rare layers of carbonate varves and siderites are widespread at deeper levels (Cores 39-47). In the lower Pliocene sequence (Cores 4857), carbonate varves representing calcareous and high calcareous pelitic and aleurite-pelitic oozes dominate again.
Some layers are enriched in diatomaceous material. Turbidites are found in Core 57.

Clay varves occurring in Cores 35-40 consist of finely dispersed pelitic consolidated sediments $(\mathrm{Md}=0.0006$ $0.0022 \mathrm{~mm}$ ). The pelitic material content in them often 


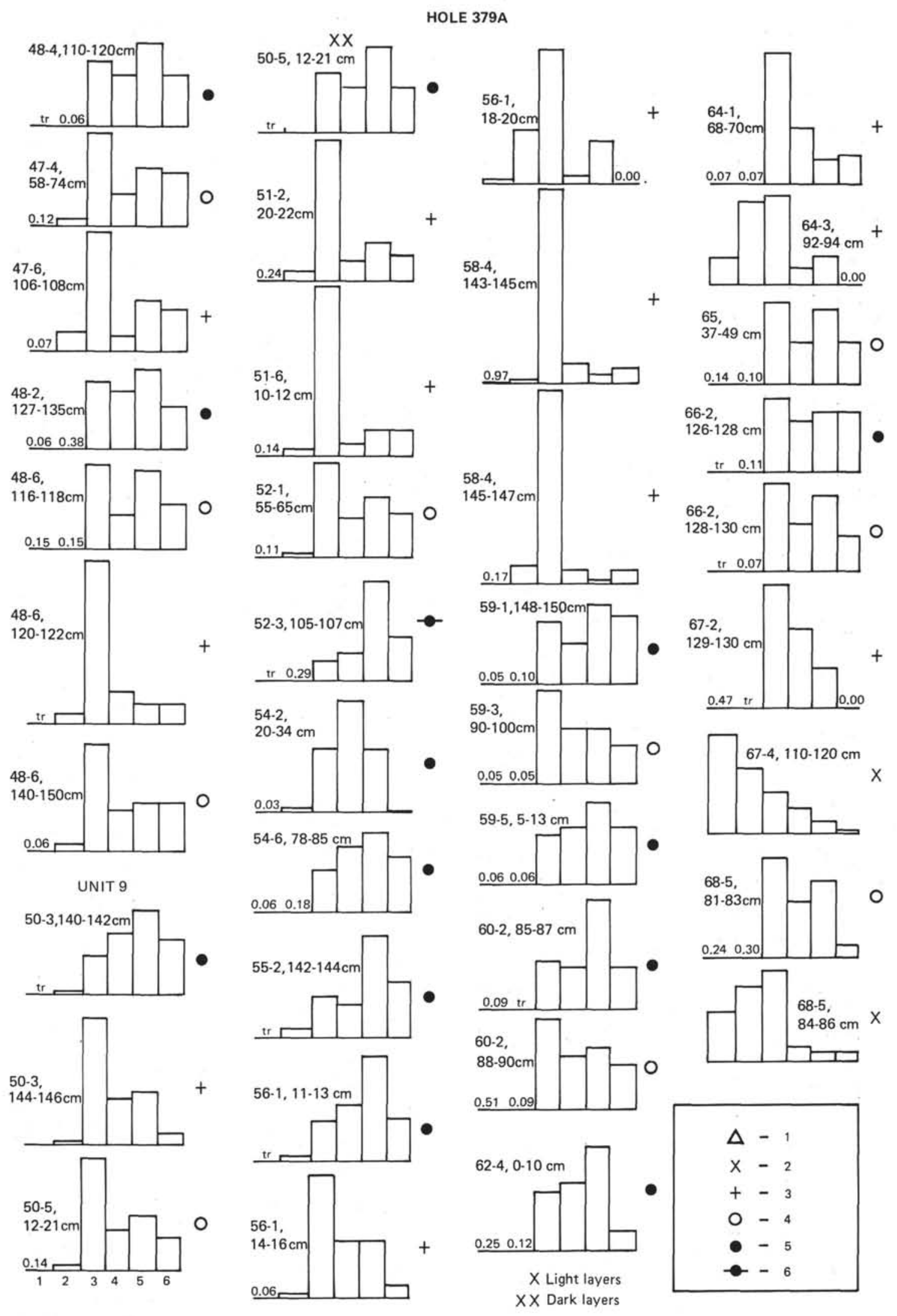

Figure 3c. Continued.

reaches more than 99 per cent $(35-4,102-112 \mathrm{~cm}, 37-3,0-12$ $\mathrm{cm}, 40-4,6-20 \mathrm{~cm}$ ) (Table 5). The grain-size profile is not uniform: in some layers subcolloidal fraction dominates, in others medium-pelitic and subcolloidal ones are predominant, sometimes both pelitic and subcolloidal fractions prevail. 
TABLE 4

Grain-Size Results, Hole 380, Leg 42B

\begin{tabular}{|c|c|c|c|c|c|c|c|c|c|}
\hline \multirow{2}{*}{$\begin{array}{l}\text { Sample } \\
\text { (Interval } \\
\text { in } \mathrm{cm} \text { ) }\end{array}$} & & \multicolumn{6}{|c|}{ Diameter of Particles (mm) } & \multirow{2}{*}{$\frac{\mathrm{Md}}{(\mathrm{mm})}$} & \multirow[b]{2}{*}{ So } \\
\hline & \multicolumn{2}{|r|}{$>0.1$} & $\begin{array}{l}0.1- \\
0.05\end{array}$ & $\begin{array}{c}0.05- \\
0.01\end{array}$ & $\begin{array}{l}0.01- \\
0.005\end{array}$ & $\begin{array}{l}0.005- \\
0.001\end{array}$ & $<0.001$ & & \\
\hline $1-1,60-68$ & \multicolumn{2}{|r|}{0.004} & 2.04 & 49.70 & 11.89 & 18.35 & 18.01 & 0.0110 & 3.4 \\
\hline $1-3,10-20$ & & 0.09 & 0.46 & 18.91 & 7.51 & 27.90 & 45.13 & 0.0012 & 3.7 \\
\hline $1-5,10-20$ & \multicolumn{2}{|r|}{0.08} & 0.75 & 12.60 & 4.51 & 33.39 & 48.66 & 0.0010 & 3.2 \\
\hline $1-6,71-81$ & & 0.004 & 1.24 & 33.26 & 11.87 & 27.25 & 26.37 & 0.0040 & 6.1 \\
\hline $2-1,62-67$ & & $74.27^{\mathrm{a}}$ & 3.28 & 4.89 & 2.10 & 5.13 & 10.33 & 0.1900 & 2.5 \\
\hline $2-2,40-52$ & & 26.31 & 26.25 & 33.87 & 2.00 & 4.00 & 7.56 & 0.0550 & 2.3 \\
\hline $2-3,57-70$ & & $27.53^{\mathrm{a}}$ & 10.06 & 17.47 & 5.59 & 17.54 & 21.80 & 0.0390 & 10.0 \\
\hline $4-1,19-28$ & & 0.64 & 0.57 & 33.60 & 12.54 & 24.78 & 27.86 & 0.0047 & 4.2 \\
\hline $4-3,18-31$ & & 0.41 & 1.15 & 19.71 & 10.13 & 29.57 & 38.96 & 0.0018 & 3.7 \\
\hline $4-4,120-133$ & & 12.02 & 4.52 & 24.74 & 8.41 & 23.42 & 26.89 & 0.0050 & 5.4 \\
\hline $5-1,82-95$ & & 2.75 & 1.61 & 29.78 & 10.33 & 24.41 & 31.12 & 0.0035 & 5.0 \\
\hline $5-2,74-92$ & & 7.23 & 4.09 & 2.77 & 11.50 & 17.85 & 56.56 & 0.0006 & - \\
\hline $6-1,93-105$ & & 4.71 & 3.14 & 39.25 & 14.29 & 20.40 & 18.21 & 0.0090 & 3.4 \\
\hline $6-4,12-33$ & & 0.92 & 4.12 & 46.37 & 13.94 & 15.50 & 19.13 & 0.0100 & 3.1 \\
\hline $7-2,122-137$ & & 0.29 & 1.97 & 30.27 & 17.94 & 39.46 & 10.06 & 0.0051 & 2.6 \\
\hline $7-3,135-145$ & & 0.22 & 0.14 & 1.44 & 20.90 & 33.98 & 43.32 & 0.0014 & 3.8 \\
\hline $7-4,42-54$ & & 0.11 & 1.17 & 23.40 & 13.72 & 25.21 & 36.38 & 0.0027 & 5.0 \\
\hline $9-1,115-130$ & & 0.25 & 2.04 & 38.30 & 9.87 & 20.51 & 29.02 & 0.0056 & 4.6 \\
\hline $10-2,125-138$ & & 0.20 & 1.03 & 32.12 & 10.62 & 20.41 & 35.62 & 0.0034 & 5.3 \\
\hline $10-4,106-132$ & & 0.06 & 0.12 & 0.64 & 34.10 & 33.75 & 31.33 & 0.0025 & 3.4 \\
\hline $13-1,0-14$ & & 0.07 & 0.75 & 26.95 & 11.81 & 26.41 & 34.01 & 0.0025 & 4.4 \\
\hline $13-5,2-14$ & & 0.13 & 0.33 & 21.69 & 11.27 & 25.25 & 41.33 & 0.0018 & 5.7 \\
\hline $13-6,4-12$ & & 0.13 & 0.60 & 1.81 & 22.48 & 37.49 & 37.49 & 0.0018 & 3.6 \\
\hline $15-1,30-45$ & & 0.62 & 8.30 & 38.73 & 10.86 & 16.39 & 25.10 & 0.0080 & 4.7 \\
\hline $15-4,30-45$ & & 2.86 & 6.29 & 2.22 & 23.00 & 30.03 & 35.60 & 0.0024 & 3.7 \\
\hline $16-1,129-145$ & & 0.07 & 0.83 & 31.47 & 15.21 & 24.96 & 27.45 & 0.0045 & 3.9 \\
\hline $17-2,130-148$ & & 0.96 & 0.89 & 1.98 & 30.20 & 36.21 & 29.76 & 0.0030 & 2.9 \\
\hline $17-4,45-60$ & & 0.06 & 0.44 & 46.00 & 15.29 & 18.97 & 19.23 & 0.0090 & 3.2 \\
\hline $18-4,18-20$ & & 0.92 & 0.21 & 1.35 & 25.66 & 33.52 & 38.34 & 0.0018 & 3.6 \\
\hline $18-5,106-125$ & & 0.003 & 0.51 & 31.17 & 14.60 & 26.29 & 27.43 & 0.0042 & 3.8 \\
\hline $18-6,130-148$ & & 0.07 & 2.78 & 37.81 & 13.71 & 22.81 & 22.81 & 0.0065 & 3.6 \\
\hline $19-1,17-19$ & & 1.30 & 1.30 & 2.82 & 25.21 & 31.98 & 37.39 & 0.0019 & 3.4 \\
\hline $19-6,58-70$ & & 0.06 & 1.14 & 44.86 & 12.19 & 15.19 & 26.55 & & \\
\hline $19-6,86-100$ & & 0.12 & 10.25 & 63.33 & 5.06 & 6.59 & 14.64 & 0.0200 & 2.1 \\
\hline $20-1,2-12$ & & 0.28 & 0.56 & 1.20 & 22.64 & 33.36 & 41.96 & 0.0016 & 3.6 \\
\hline $20-6,40-50$ & & 0.15 & 0.61 & 23.86 & 9.52 & 25.79 & 40.06 & 0.0020 & 6.1 \\
\hline $21-3,56-69$ & & 0.08 & 2.28 & 38.61 & 10.43 & 15.99 & 31.60 & 0.0050 & 6.4 \\
\hline $21-6,48-61$ & & 0.06 & 1.01 & 32.48 & 6.50 & 25.99 & 33.95 & 0.0026 & 4.0 \\
\hline $23-6,100-110$ & & 0.18 & 0.43 & 15.82 & 7.73 & 27.23 & 48.60 & 0.0011 & 4.3 \\
\hline $24-1,109-111$ & & 0.22 & 0.11 & 0.33 & 30.04 & 37.28 & 32.02 & 0.0025 & 2.9 \\
\hline $24-2,130-140$ & & 0.14 & 0.14 & 0.28 & 28.20 & 35.62 & 35.62 & 0.0024 & 3.4 \\
\hline $24-5,0-8$ & & 0.07 & 0.28 & 10.55 & 4.93 & 23.67 & 60.47 & & \\
\hline $25-6,14-16$ & & 0.40 & 0.90 & 2.44 & 27.06 & 34.60 & 34.60 & 0.0025 & 3.2 \\
\hline $26-4,55-65$ & & 0.32 & 1.36 & 17.12 & 0.88 & 13.83 & 66.48 & 0.0004 & 4.8 \\
\hline $27-3,1-13$ & & 0.63 & 1.71 & 21.16 & 6.21 & 20.53 & 49.75 & 0.0010 & 7.4 \\
\hline $28-1,124-136$ & & 0.14 & 0.41 & 22.34 & 7.51 & 24.44 & 45.16 & 0.0014 & 6.0 \\
\hline $28-1,134-150$ & & tr. & 0.19 & 25.50 & 7.99 & 21.04 & 45.27 & 0.0015 & 8.4 \\
\hline $30-1,94-110$ & & tr. & 0.19 & 36.28 & 12.81 & 20.67 & 30.04 & 0.0050 & 5.2 \\
\hline $30-2,82-85$ & & 0.18 & 0.72 & 9.77 & 22.17 & 28.19 & 38.97 & 0.0100 & 2.0 \\
\hline $30-2,85-88$ & & 0.18 & 1.01 & 18.51 & 18.92 & 30.69 & 30.69 & 0.0030 & 3.4 \\
\hline $30-2,88-91$ & & 0.21 & 1.78 & 14.17 & 28.28 & 28.28 & 27.28 & 0.0039 & 3.1 \\
\hline $32-3,80-90$ & & 0.06 & 1.01 & 30.81 & 12.20 & 23.93 & 31.99 & 0.0035 & 4.8 \\
\hline $33-3,95-110$ & & tr. & 1.31 & 44.24 & 13.58 & 17.27 & 23.59 & 0.0090 & 3.9 \\
\hline $35-1,111-123$ & & 0.06 & 1.41 & 44.47 & 12.34 & 15.30 & 26.06 & 0.0090 & 4.5 \\
\hline $35-3,19-42$ & & 1.86 & 5.75 & 30.77 & 13.12 & 21.38 & 27.12 & 0.0050 & 6.2 \\
\hline $36-2,28-38$ & & 0.36 & 5.74 & 37.83 & 11.20 & 21.82 & 23.04 & 0.0075 & 4.4 \\
\hline $36-3,58-68$ & & 1.45 & 1.65 & 7.85 & 10.62 & 31.20 & 47.23 & 0.0011 & 3.3 \\
\hline $37-1,73-83$ & & tr. & 0.07 & 7.70 & 7.70 & 26.93 & 57.60 & 0.0008 & 3.3 \\
\hline $38-2,73-85$ & & tr. & 0.07 & 15.51 & 12.08 & 13.08 & 59.25 & 0.0005 & - \\
\hline $39-1,48-62$ & & 0.27 & 1.23 & 17.14 & 5.67 & 33.20 & 42.49 & 0.0013 & 3.7 \\
\hline $39-5,0-12$ & & 0.76 & 1.53 & 2.01 & 34.47 & 32.80 & 28.43 & 0.0030 & 3.1 \\
\hline $40-1,120-135$ & & 0.06 & 0.12 & 7.03 & 5.08 & 29.30 & 58.41 & 0.0008 & 2.9 \\
\hline $\begin{array}{l}\text { Sample } \\
\text { (Interval }\end{array}$ & & & mo & 1 art & (Im) & & & & \\
\hline in $\mathrm{cm}$ ) & $4-3$ & $3-2$ & $2-1$ & $1-0.5$ & $0.5-0.25$ & 0.25 & & & \\
\hline $2-1,62-67$ & 0.11 & 3.05 & 4.76 & 15.23 & 16.39 & & & & \\
\hline $2-2,40-52$ & 1.00 & 0.75 & 1.50 & 4.75 & 5.94 & & & & \\
\hline $2-3,57-70$ & - & 0.42 & 0.35 & 1.96 & 5.31 & 19. & & & \\
\hline
\end{tabular}

${ }^{\mathrm{a}} \mathrm{Grain}$ size of coarse fractions. 
TABLE 5

Grain-Size Results, Hole 380A, Leg 42B

\begin{tabular}{|c|c|c|c|c|c|c|c|c|}
\hline \multirow{2}{*}{$\begin{array}{l}\text { Sample } \\
\text { (Interval } \\
\text { in } \mathrm{cm} \text { ) }\end{array}$} & \multicolumn{7}{|c|}{ Diameter of Particles (mm) } & \multirow[b]{2}{*}{ So } \\
\hline & $>0.1$ & $\begin{array}{l}0.1- \\
0.05\end{array}$ & $\begin{array}{c}0.95- \\
0.01\end{array}$ & $\begin{array}{l}0.01- \\
0.005\end{array}$ & $\begin{array}{r}0.005- \\
0.001\end{array}$ & $<0.001$ & $\begin{array}{c}\mathrm{Md} \\
(\mathrm{mm})\end{array}$ & \\
\hline $1-3,45-50$ & 0.14 & 0.14 & 0.21 & 18.26 & 33.83 & 47.42 & 0.0011 & 0. \\
\hline $1-3,50-60$ & 0.84 & 0.14 & 1.34 & 24.53 & 26.56 & 46.59 & 0.0013 & 4.2 \\
\hline $3-2,74-87$ & tr. & 0.26 & 29.70 & 19.00 & 36.19 & 14.85 & 0.0050 & 2.6 \\
\hline $4-1,32-45$ & 0.06 & 0.12 & 6.48 & 6.43 & 32.64 & 54.28 & 0.0009 & 2.7 \\
\hline $4-3,60-65$ & 0.15 & 0.15 & 0.53 & 18.78 & 31.32 & 49.07 & 0.0011 & 3.5 \\
\hline $4-3,65-70$ & 0.07 & 0.07 & 0.21 & 23.67 & 25.91 & 50.07 & 0.0010 & 3.5 \\
\hline $4-5,38-51$ & 0.06 & 0.49 & 8.12 & 4.64 & 32.17 & & 009 & 2.2 \\
\hline $5-4,61-74$ & 0.32 & 0.32 & 5.80 & 9.34 & 46.26 & 37.95 & 0.0015 & 2.2 \\
\hline $6-3,106-119$ & 2.26 & 0.56 & 11.78 & 10.86 & 34.91 & 39.63 & 0.0015 & 3.0 \\
\hline $6-4,0-18$ & 1.31 & 0.85 & 13.42 & 15.59 & 31.81 & 36.02 & 0.0021 & 3.8 \\
\hline $8-4,129-150$ & 2.06 & 0.69 & 2.48 & 1.99 & 24.55 & 68.22 & 0.0004 & 2.8 \\
\hline $9-2,128-142$ & 0.06 & 0.24 & 12.97 & 9.68 & 31.50 & 45 & 0.0011 & 3.1 \\
\hline $9-3,72-84$ & 0.07 & 0.54 & 4.82 & 6.78 & 34.06 & 53.73 & 0.0008 & 2.8 \\
\hline $9-5,78-95$ & 1.06 & 2.62 & 16.54 & 18.10 & 29.24 & 32.43 & 0.0030 & 3.9 \\
\hline $9-6,97-106$ & 1.43 & 0.91 & 13.92 & 20.16 & 31.09 & 32.79 & 0.0030 & 3.2 \\
\hline $10-2,62-74$ & 0.24 & 0.43 & 10.59 & 3.83 & 31.10 & 53.80 & 0.0009 & 3.0 \\
\hline $11-6,58-69$ & 0.67 & 0.73 & 19.43 & 8.95 & 27.47 & 42.75 & 0.0015 & 4.2 \\
\hline $12-4,0-16$ & tr. & 0.06 & 20.90 & 12.09 & 32.99 & 33.95 & 0.0002 & 3.4 \\
\hline $12-6,49-61$ & 1.85 & 0.46 & 8.98 & 5.35 & 32.76 & 50.59 & 0.0009 & 2.5 \\
\hline $13-1,100-111$ & 0.06 & 0.06 & 24.69 & 12.72 & 30.24 & 31.22 & 0.0029 & 3.8 \\
\hline $14-2,62-67$ & 0.98 & 0.81 & 21.42 & 11.43 & 29.79 & 35.56 & 0.0025 & 4.0 \\
\hline $14-3,15-28$ & 0.20 & 0.20 & 20.00 & 15.85 & 34.54 & 29.21 & 0.0026 & 3.1 \\
\hline $14-3,136-147$ & 0.07 & 0.14 & 0.75 & 14.24 & 38,65 & 15 & 0.0012 & 3.0 \\
\hline $14-6,67-79$ & 1.16 & 0.75 & 15.95 & 10.91 & 42.06 & 29.17 & 0.0021 & 2.5 \\
\hline $15-2,40-42$ & 0.07 & 0.07 & 0.21 & 20.89 & 33.71 & 45.05 & 0.0014 & 3.3 \\
\hline $15-3,26-32$ & 0.12 & 1.72 & 23.83 & 6.26 & 34.83 & 33.23 & 0.0020 & 3.5 \\
\hline $17-2,56-70$ & 0.31 & 0.43 & 43.33 & 19.15 & 21.36 & 15.42 & 0.0081 & 2.5 \\
\hline $17-2,111-123$ & 0.07 & 0.40 & 6.44 & 6.30 & 40.04 & 46 & 11 & 2.3 \\
\hline $18-3,33-48$ & 1.56 & 0.06 & 22.44 & 17.73 & 29.40 & 28.84 & 0.0035 & 3.6 \\
\hline $19-2,0-16$ & 0.68 & 0.12 & 10.65 & 9.40 & 26.77 & 52.37 & 0.0009 & 3.0 \\
\hline $19-3,31-33$ & 0.31 & 0.14 & 0.34 & 22.01 & 32.29 & 44.91 & 0.0014 & 3.3 \\
\hline $19-4,0-16$ & 0.13 & 0.32 & 13.53 & 12.31 & 29.77 & 43.94 & 0.0014 & 3.7 \\
\hline $20-2,39-51$ & 0.86 & 0.60 & 18.06 & 8.63 & 24.04 & 47 & 11 & 5.3 \\
\hline $20-5,22-24$ & 0.13 & 0.13 & 0.85 & 27.89 & 35.50 & 0 & 23 & 3.3 \\
\hline $22-3,84-96$ & 2.09 & 0.25 & 33.63 & 13.58 & 22.40 & 28.04 & 0.0044 & 4.3 \\
\hline $23-3,21-33$ & 0.43 & 0.12 & 26.68 & 17.66 & 25.37 & 29.73 & 0.0039 & 4.0 \\
\hline $23-5,77-87$ & 0.39 & 0.19 & 33.25 & 15.48 & 21.34 & 29.34 & 0.0050 & 4.7 \\
\hline $25-2,45-61$ & tr. & 0.12 & 30.55 & 17.80 & 22.93 & 28.60 & 0.0045 & 3.8 \\
\hline $25-2,126-136$ & 0.19 & 0.62 & 16.85 & 9.42 & 30.71 & 42.20 & 14 & 3.7 \\
\hline $25-3,26-28$ & 0.27 & 0.13 & 0.33 & 26.00 & 31.45 & 41.82 & 0.0018 & 4.0 \\
\hline $26-2,71-87$ & 0.19 & 0.06 & 23.61 & 11.19 & 26.58 & 38.36 & 0.0022 & 5. \\
\hline $27-5,0-8$ & 0.15 & 0.15 & 0.66 & 20.63 & 35.24 & 43.17 & 0.0015 & $4 .(1-x)-1$ \\
\hline $30-1,108-120$ & 0.18 & 0.18 & 9.02 & 8.10 & 35.97 & 46.54 & 0.0011 & 2.2 \\
\hline $30-2,38-50$ & 0.38 & 0.19 & 24.63 & 17.92 & 24.51 & 32.36 & 0.0030 & 4.6 \\
\hline $31-1,40-55$ & 2.81 & 0.32 & 8.82 & 6.39 & 35.10 & 5 & 11 & 2.7 \\
\hline $32-6,34-47$ & 0.13 & 0.25 & 30.41 & 20.36 & 27.42 & 21.43 & 0.0 & 2. \\
\hline $34-3,27-44$ & 0.27 & 0.07 & 10.29 & 12.06 & 39.71 & 37.60 & 0.0013 & 2. \\
\hline $34-5,112-123$ & 0.07 & 0.07 & 13.79 & 12.97 & 41.45 & 31.64 & 0.0016 & 2. \\
\hline $35-3,58-71$ & 0.06 & 0.06 & 7.68 & 7.55 & 32.28 & 52.36 & 0.0009 & 2. \\
\hline $35-4,102-112$ & 0.13 & 0.07 & 0.21 & 31.13 & 30.75 & 37.71 & .0022 & 3.5 \\
\hline $37-3,0-12$ & 0.06 & 0.06 & 0.84 & 1.03 & 29 & 68.17 & 6 & \\
\hline $38-3,0-16$ & 0.14 & 0.07 & 1.73 & 4.36 & 36.68 & 55.02 & 0.0009 & \\
\hline $38-5,62-75$ & 0.23 & 0.14 & 5.93 & 11.51 & 37.46 & 44.61 & 0.0013 & 3. \\
\hline $40-4,6-20$ & 0.13 & 0.13 & 0.26 & 24.26 & 37.61 & 37.61 & 0.0017 & 3.2 \\
\hline $41-4,10-20$ & tr. & 0.31 & 29.20 & 18.27 & 26.68 & 25.53 & 0.0043 & 3.5 \\
\hline $41-6,108-122$ & tr. & 0.08 & 31.13 & 16.77 & 26.61 & 25.40 & 0.0040 & 3.7 \\
\hline $42-4,33-35$ & 0.13 & 0.07 & 0.21 & 16.67 & 37.52 & 45.40 & 0.0013 & 3. \\
\hline $43-1,0-13$ & tr. & 0.89 & 29.81 & 14.77 & 24.80 & 29.72 & 0.0037 & 4. \\
\hline $43-3,112-126$ & tr. & 1.71 & 30.49 & 18.32 & 26.56 & 22.92 & 0.0052 & 3. \\
\hline $44-5,130-140$ & tr. & 1.03 & 28.93 & 19.16 & 25.84 & 25.04 & 0.0046 & 3.5 \\
\hline $45-3,112-125$ & tr. & 0.64 & 24.56 & 11.83 & 21.01 & 41.94 & 0.0019 & 6.3 \\
\hline $46-3,1-10$ & tr. & 1.70 & 38.93 & 15.92 & 14.67 & 28.76 & 0.0070 & 4. \\
\hline $47-1,50-60$ & tr. & 0.84 & 33.36 & 15.91 & 15.91 & 33.97 & 0.0050 & 6. \\
\hline $49-5,0-15$ & 0.07 & 0.66 & 25.18 & 12.82 & 28.72 & 32.53 & 0.0027 & 4.5 \\
\hline $50-2,130-140$ & tr. & 0.40 & 8.93 & 20.14 & 36.06 & 34.45 & 0.0025 & 3.5 \\
\hline $51-4,34-50$ & 0.84 & 2.52 & 25.35 & 14.57 & 24.23 & 32.49 & 0.0035 & 4.6 \\
\hline $52-2,0-12$ & tr. & 3.27 & 36.19 & 15.12 & 19.41 & 26.01 & 0.0060 & 4.2 \\
\hline
\end{tabular}


TABLE 5-Continued

\begin{tabular}{lccccccccc}
\hline \multirow{2}{*}{$\begin{array}{l}\text { Sample } \\
\text { (Interval } \\
\text { in cm) }\end{array}$} & $>0.1$ & $0.1-$ & $0.05-$ & 0.01 & $0.01-$ & $0.005-$ & & Md & \\
\hline $53-2,1-15$ & 0.96 & 6.69 & 36.16 & 14.03 & 17.57 & 24.58 & 0.0070 & 4.6 \\
$54-1,66-78$ & 0.32 & 1.95 & 38.39 & 14.77 & 19.78 & 24.79 & 0.0070 & 3.9 \\
$56-1,95-105$ & 0.45 & 6.10 & 31.15 & 11.85 & 18.22 & 32.23 & 0.0044 & 5.9 \\
$60-1,13-19$ & 0.30 & 1.26 & 36.59 & 11.62 & 13.26 & 36.96 & 0.0050 & 8.0 \\
$60-4,65-80$ & tr. & 0.45 & 33.90 & 14.16 & 30.10 & 21.39 & 0.0044 & 3.2 \\
$62-2,0-15$ & 3.90 & 9.63 & 38.65 & 8.78 & 10.99 & 28.04 & 0.0110 & 6.7 \\
$64-4,69-80$ & 0.06 & 3.17 & 40.82 & 10.66 & 19.24 & 26.03 & 0.0080 & 3.0 \\
$71-2,13-21$ & 0.07 & 9.62 & 45.98 & 9.46 & 10.74 & 24.11 & 0.0120 & 4.5 \\
$73-3,16-27$ & 0.06 & 2.77 & 45.57 & 12.98 & 12.36 & 26.26 & 0.0100 & 5.2 \\
\hline
\end{tabular}

SITE 380

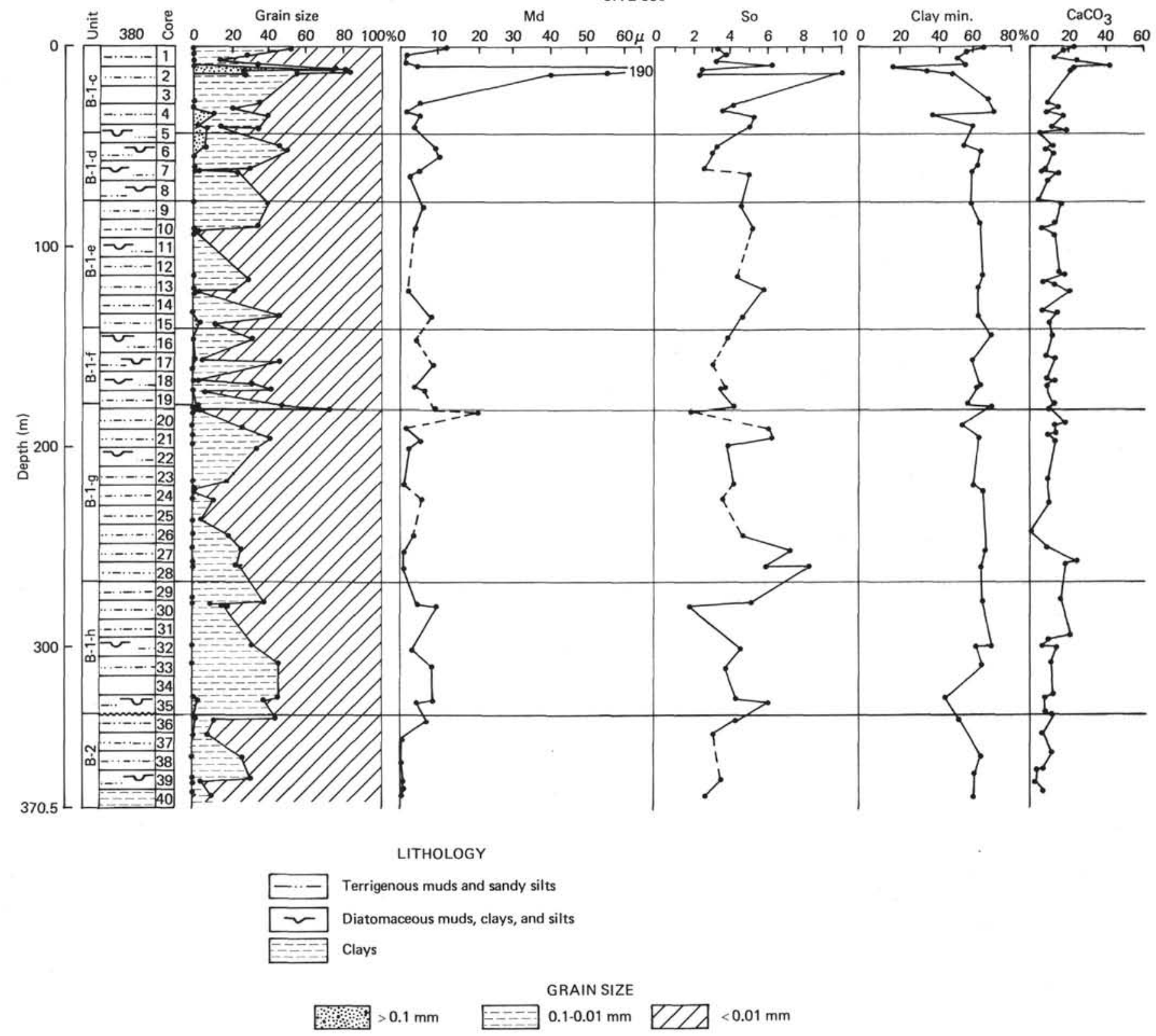

Figure 4. Grain-size fractions, Md and So, Site 380. 


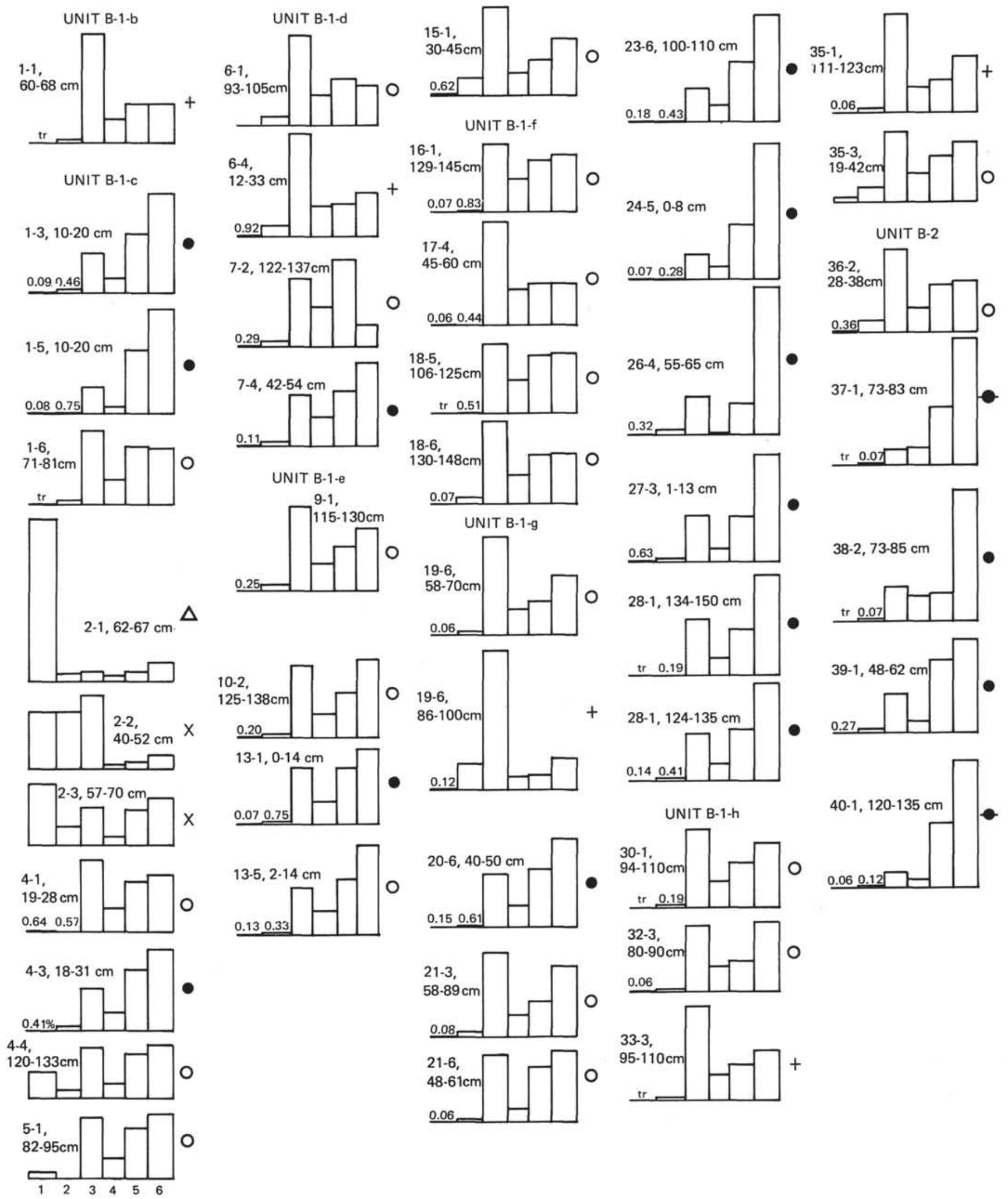

Figure 5. Grain-size histograms of Site 380 sediments. 


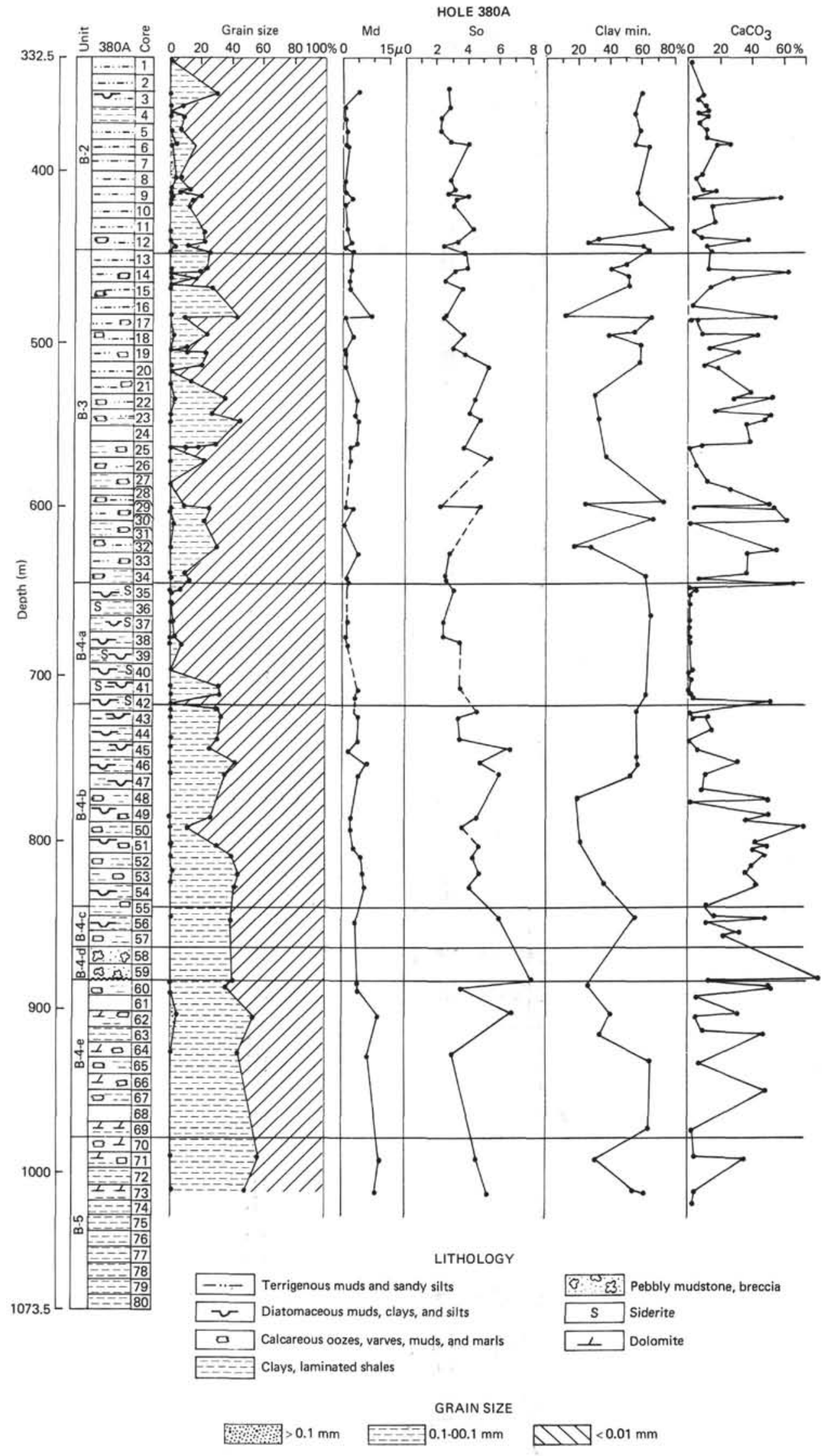

Figure 6. Grain-size fractions, Md and So, Hole $380 \mathrm{~A}$. 
UNIT B-2

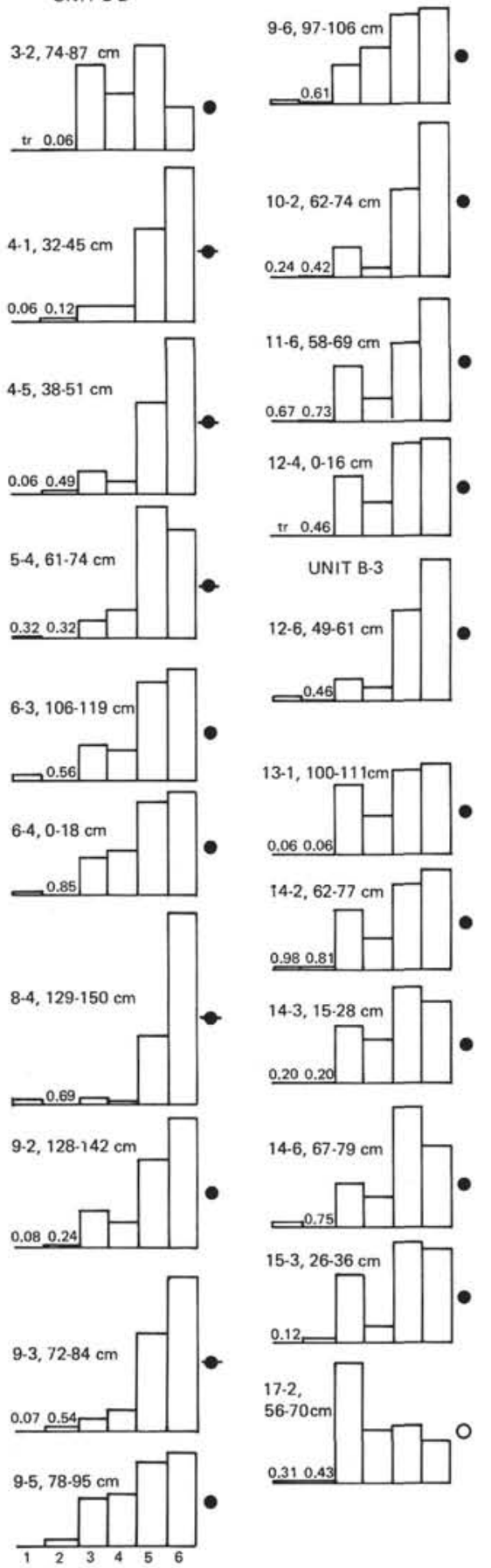

HOLE 380A
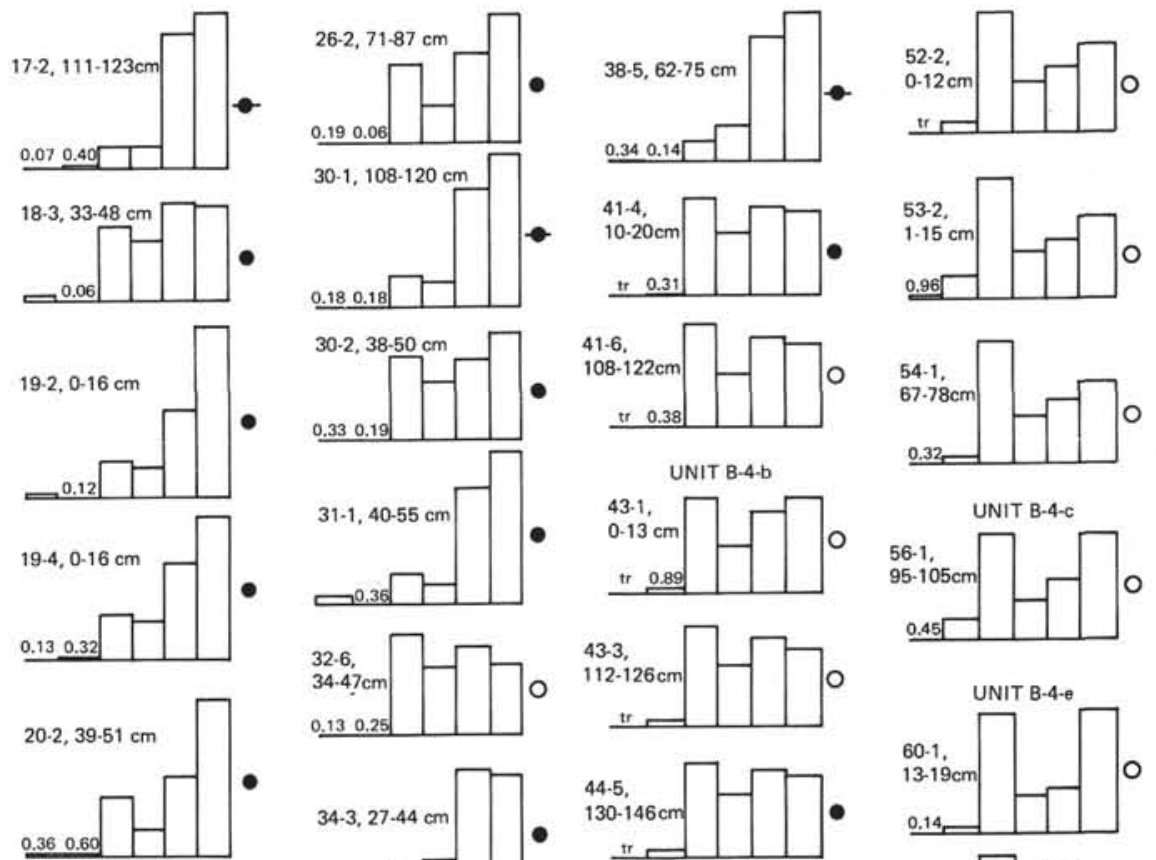

UNIT B-4-b
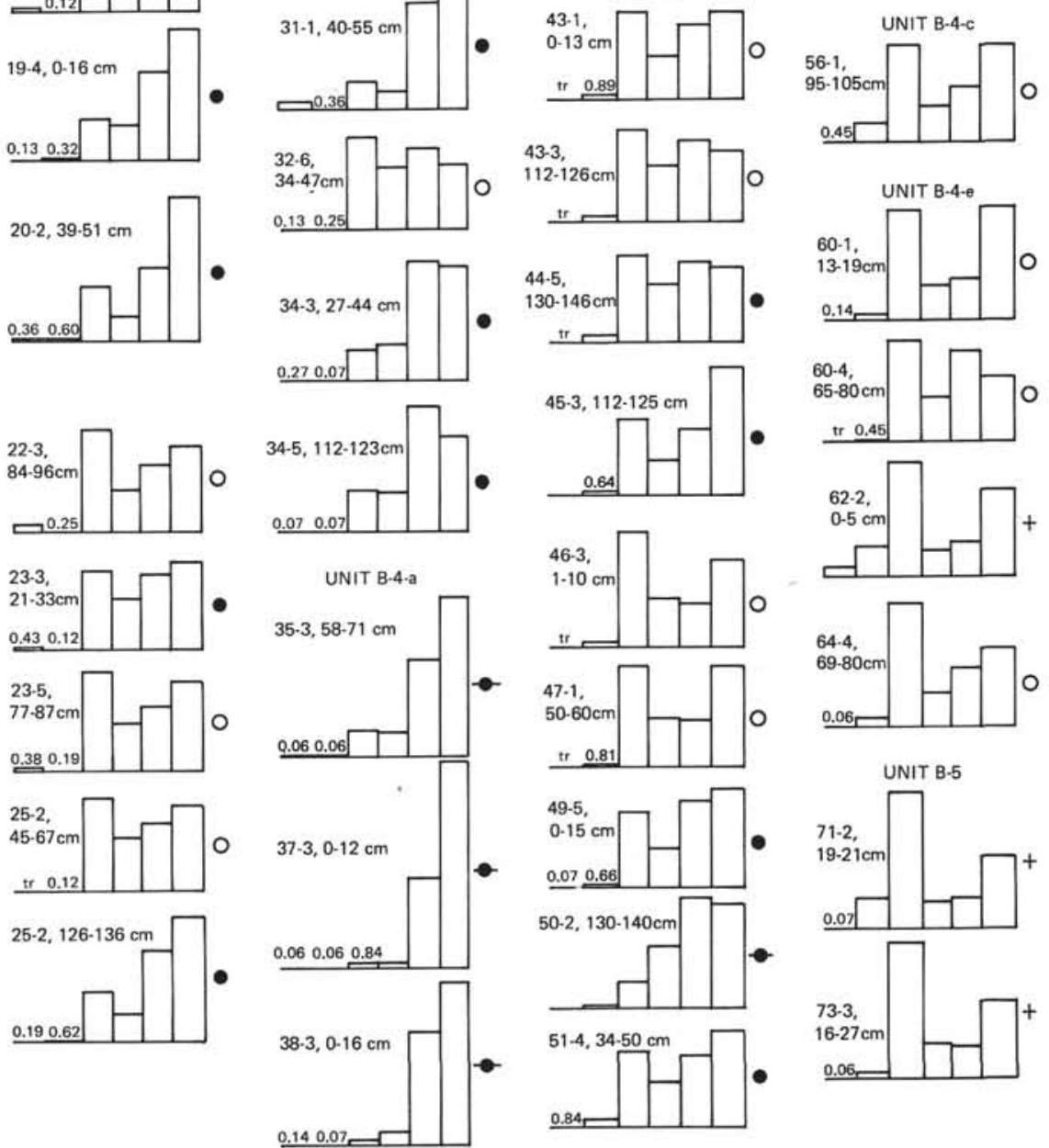

Figure 7. Grain-size histograms of Hole $380 \mathrm{~A}$ sediments.

Diatomaceous sediments enriched in organic matter (41-4, $10-20 \mathrm{~cm}, 41-6,108-122 \mathrm{~cm}, 42-4,33-35 \mathrm{~cm}, 43-3,112-126$ $\mathrm{cm}, 44-5,130-140 \mathrm{~cm}, 45-3,112-125 \mathrm{~cm}, 46-3,1-10 \mathrm{~cm}$, $47-1,50-60 \mathrm{~cm})$ correspond either to the type of aleuritepelitic muds $(\mathrm{Md}=0.0037-0.0052 \mathrm{~mm})$ or to pelitic ones $(\mathrm{Md}=0.0019-0.0043 \mathrm{~mm})$. Fine aleuritic, medium pelitic, and subcolloidal fractions often with similar contents prevail in them. Some very thin interbeds of fine aleuritic material in these muds consist almost entirely of diatom skeletons; others, besides diatoms, also include organic detritus.

Carbonate varves by grain-size composition correspond to pelitic and aleurite-pelitic sediments. In their grain-size pro- file subcolloidal fraction prevails, but in the case of diatom enrichment, as well as subcolloidal fraction, fine aleuritic ones dominate. As a whole, carbonate varves are granulometrically similar to clay ones.

Sideritic interbeds are characterized by the aleuritemicrogranular (relict-diatomic) texture. The grain size principally is $<0.01 \mathrm{~mm}$.

Some samples from lithologically heterogeneous units (Units B-4-d, e and B-5) were studied in the Miocene sequence (Table 5, Figures 6 and 7). Sample 59-1, 117-119 cm studied in thin section represents the calcareous rock of aleurite-microgranular (relict-organogenous) texture. 
In Unit B-4-e, formed by carbonate and clay varves, as well as lithified dolomite clay and dolomitized calcareous in them. The interbeds studied may be referred to as calcareous and marly calcareous consolidated silty clays.

Clay diatomites and dolomitic-clay deposits $(63-3,112-$ $116 \mathrm{~cm}, 69-3,72-74 \mathrm{~cm}, 69-4,53-58 \mathrm{~cm}$ ) are characterized by microgranular-pelitomorphic texture (dolomite is usually $0.0044-0.008 \mathrm{~mm})$ and fine-silty muds $(\mathrm{Md}=0.011 \mathrm{~mm})$ (Table 5). Fine aleuritic and subcolloidal fractions dominate clay deposits, the grain size was studied in some layers (Cores 60-64). They correspond to aleurite-pelitic ( $\mathrm{Md}=$ microgranular). Dolomitized calcareous clay in Sample $64-4,20-22 \mathrm{~cm}$ is of aleurite-microgranular-pelitomorphic texture.

The deposits in Unit B-5 are compact, thinly laminated aleuritic clays poor in organic and calcareous matter and enriched in iron sulfides. Thinly laminated layers in Cores $71-73$ are find silty deposits $(\mathrm{Md}=0.010-0.012 \mathrm{~mm})$. Fine aleuritic and subcolloidal fractions are abundant here.

Interbeds of lithified dolomitic clay $(70-5,121) 123 \mathrm{~cm}$, $73-1,58-60 \mathrm{~cm})$ are characterized by a microgranularpelitomorphic texture.

In the Pleistocene sequence, glacial units are mainly pelitic and aleurite-pelitic muds, but some parts of them are appreciably enriched in turbidites consisting of sandy silt sediments (fine-grained sands, coarse and fine silts) and terrigenous muds.

Turbidites are most widespread in the upper part of the Würm sediments sequence (Unit B-1-c) and in the lower part of the Mindel ones (Unit B-1-h).

Interbeds of finely dispersed pelitic muds are found in different parts of glacial units. They are most widespread in Riss deposits.

At Holes 380/380A repeated changes in grain size occurs.

Variable grain sizes, from fine silty muds to finely dispersed pelites, occur in interglacial Pleistocene units as well as in glacial sequences. The silty layers are not restricted to any certain part of the strata as they are in glacial units.

Sediments enriched in siliceous diatomaceous matter are represented by a wide grain-size spectrum: from fine silty muds to pelitic ones. In diatomaceous pelitic muds the fine aleuritic fraction content increases as compared with clays.

Eopleistocene sediments corresponding to warm climatic intervals (the upper part of Unit B-2) consist mostly of finely dispersed clays, whereas sediments formed during lowering temperatures are of a wider grain-size spectrum: from sands to finely dispersed muds and oozes (the lower part of Units B-2 and B-3). Turbidites together with sands and silts form a set of interbeds only in the upper part of sequence (Cores 5-11, Hole 380A). However, the greater part of the strata consists of alternating interbeds of pelitic and aleurite-pelitic sediments. Finely dispersed pelitic muds are met in different portions of the sequence.

In spite of sharp changes in carbonate contents of sediments (from less than $10 \%$ to more than to $50 \% \mathrm{CaCO}_{3}$ ), the grain-size profile of pelitic and aleurite-pelitic oozes and muds is altered slightly, indicating that carbonate material is distributed in the grain-size spectrum like the clastic clayey one, which, in turn, suggests a terrigenous origin for most of the carbonates.
Finely dispersed pelitic muds are characterized by low calcareous content (less than $10 \% \mathrm{CaCO}_{3}$ ), that is, they consist entirely of clay material.

The Pliocene-Miocene sequence, distinguished by sharply changing contents of carbonates, organic matter, and diatomic silica, consists of alternating mostly pelitic and aleurite-pelitic sediments. Finely dispersed pelitic sediments visibly spread in the upper sequence part (Unit B-4-a) and fine silty deposits and sandstones are widespread in the lower portion (Units B-4-e and B-5).

Coarse clastics and cobble-sized rocks occur in the middle part of the Pliocene-Miocene sequence (Cores 58-59).

Finely dispersed pelitic sediments are most commonly low in calcareous content. Only single interbeds contain high amounts of $\mathrm{CaCO}_{3}$. The latter are characterized by a decreased content of subcolloidal fraction and the increased concentration of coarse pelites as compared to low calcareous finely dispersed pelitic muds.

Low siliceous sediments with various amounts of $\mathrm{CaCO}_{3}$, and enriched in diatoms and organic matter, are most commonly represented by pelitic muds and oozes with more than 70 per cent of pelitic $(<0.01 \mathrm{~mm})$ fraction.

\section{SITE 381}

Detailed lithologic investigations of the Site 381 area were carried out by R/V Vityaz in 1960 (Emelyanov and Shimkus, 1962). This is a steep continental slope of the Bosporus area with two submarine valleys and submerged ridges trending in a northeastern direction and with rater steep flanges. The most complete sediment sequence was found at Station 4754-5, depth 1193 meters. Recent sediments consist of dark gray clays and aleurite-pelitic muds. Strata of upper Holocene sediments include alternating clay and microlaminated nannofossil oozes (thickness of 60 to $115 \mathrm{~cm}$ ). The middle Holocene (Old Black Sea) horizon comprises microlaminated silty clays and fine silty muds with a relatively high content of organic matter (1-2\% Corg.) in a thickness of $347 \mathrm{~cm}$. The lower Holocene sediments are missing. Only the top of the upper Würm (middle-Novoeuxinic) sediments (thickness $254 \mathrm{~cm}$ ) consisting of dark gray, black and yellow gray clays, and aleurite-pelitic muds were recovered in the core. An admixture of shell detritus occurs in the upper part of the sequence. The pelitic content increases rapidly $(84.27 \%)$ in clays in the lower part of the strata.

Upper and middle Holocene deposits are absent on the steep valley slopes as well as the bottom of it, and viscous Novoeuxinic clays are exposed on the surface.

The top of the Site 381 sequence begins in Mindel-Riss deposits (Unit 3 ). Their grain-size composition corresponds to pelitic muds (Table 6; Figures 8 and 9). In some interbeds $(1-3,0-20 \mathrm{~cm})$ these muds are finely dispersed. Layers enriched in silty and sandy material (shell detritus) are of minor importance $(1-1,68-70 \mathrm{~cm})$; it is poorly sorted fine silty mud $(\mathrm{Md}=0.025 \mathrm{~mm})$.

Mindel deposits (Unit 3, Cores 5-17) comprise terrigenous pelitic and aleurite-pelitic muds. Interbeds with size grading (turbidites) occur sporadically. Either subcolloidal fraction or both medium pelitic and subcolloidal ones dominate in the grain-size profile of pelitic muds, and fine aleuritic and subcolloidal fractions prevail in aleurite-pelitic sediments. 
TABLE 6

Grain-Size Results, Site 381, Leg 42B

\begin{tabular}{|c|c|c|c|c|c|c|c|c|}
\hline \multirow{2}{*}{$\begin{array}{l}\text { Sample } \\
\text { (Interval } \\
\text { in } \mathrm{cm} \text { ) }\end{array}$} & \multicolumn{7}{|c|}{ Diameter of Particles (mm) } & \multirow[b]{2}{*}{ So } \\
\hline & $>0.1$ & $\begin{array}{l}0.1- \\
0.05\end{array}$ & $\begin{array}{l}0.05- \\
0.01\end{array}$ & $\begin{array}{l}0.01- \\
0.005\end{array}$ & $\begin{array}{l}0.005- \\
0.001\end{array}$ & $<0.001$ & $\begin{array}{c}\mathrm{Md} \\
(\mathrm{mm})\end{array}$ & \\
\hline $1-1,68-70$ & 38.76 & 3.21 & 22.72 & 22.72 & 10.12 & 2.47 & 0.0250 & 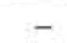 \\
\hline $1-3,0-20$ & 0.38 & 0.38 & 7.12 & 14.74 & 22.11 & 55.27 & 0.0008 & 4.0 \\
\hline $3-2,55-75$ & 0.40 & 0.88 & 17.19 & 7.31 & 26.91 & 47.30 & 0.0011 & 4.3 \\
\hline $4-2,115-140$ & 0.59 & 1.44 & 12.59 & 6.51 & 28.32 & 50.55 & 0.0010 & 3.6 \\
\hline $5-3,115-135$ & 0.90 & 1.17 & 13.45 & 8.21 & 18.32 & 57.94 & 0.0055 & - \\
\hline $7-4,125-145$ & 0.26 & 0.26 & 4.41 & 1.96 & 19.44 & 73.69 & 0.0004 & $\sim 3.0$ \\
\hline $8-3,126-140$ & 0.35 & 4.71 & 33.48 & 16.91 & 16.39 & 28.16 & 0.0065 & 4.9 \\
\hline $8-5,40-63$ & 1.35 & 2.62 & 20.05 & 13.62 & 25.55 & 86.80 & 0.0025 & 5.3 \\
\hline $9-1,147-149$ & 1.37 & 0.88 & 41.00 & 11.15 & 18.79 & 26.81 & 0.0067 & 4.7 \\
\hline $9-4,135-150$ & 0.49 & 0.93 & 10.48 & 13.48 & 38.80 & 35.80 & 0.0020 & 3.4 \\
\hline $9-6,70-90$ & 0.16 & 0.16 & 8.38 & 16.35 & 30.40 & 44.54 & 0.0012 & 4.1 \\
\hline $11-2,0-15$ & 1.89 & 3.46 & 18.43 & 11.04 & 28.37 & 36.80 & 0.0023 & 5.3 \\
\hline $13-3,90-105$ & 0.06 & 0.77 & 6.74 & 6.99 & 27.41 & 58.02 & 0.0007 & 2.9 \\
\hline $14-3,0-20$ & 0.26 & 0.32 & 31.76 & 17.75 & 22.65 & 27.31 & 0.0052 & 4.0 \\
\hline $15-5,135-150$ & 1.19 & 0.66 & 15.91 & 17.36 & 31.35 & 33.53 & 0.0029 & 3.8 \\
\hline $16-5,0-20$ & 0.54 & 1.00 & 27.39 & 16.40 & 20.70 & 33.89 & 0.0040 & 5.3 \\
\hline $17-3,135-150$ & 2.27 & 0.87 & 7.62 & 11.62 & 32.33 & 45.22 & 0.0012 & 3.5 \\
\hline $18-2,0-15$ & 59.61 & 0.45 & 5.46 & 23.95 & 2.79 & 7.74 & - & - \\
\hline $19-1,0-15$ & 0.12 & 0.18 & 35.44 & 6.74 & 12.84 & 44.67 & 0.0002 & - \\
\hline $19-2,92-102$ & 0.08 & tr. & 1.35 & 6.86 & 18.37 & 73.33 & 0.0012 & 4.2 \\
\hline $22-1,40-55$ & 0.09 & 0.52 & 8.21 & 12.79 & 31.03 & 47.36 & 0.0011 & 4.0 \\
\hline $22-3,40-55$ & 0.08 & 0.46 & 13.83 & 14.13 & 30.94 & 40.56 & .0019 & 4.0 \\
\hline $24-1,48-63$ & 0.08 & 0.55 & 12.80 & 13.43 & 35.19 & 37.94 & 18 & 3.4 \\
\hline $25-2,40-55$ & 0.09 & 0.38 & 12.02 & 13.26 & 34.92 & 39.31 & 0.0017 & 3.7 \\
\hline $26-3,40-50$ & 0.10 & 0.70 & 21.46 & 14.04 & 30.59 & 33.10 & 0.0024 & 4.0 \\
\hline $27-2,50-65$ & 0.11 & 0.42 & 17.15 & 12.89 & 28.75 & 40.68 & 0.0018 & 5.0 \\
\hline $28-3,70-85$ & tr. & 1.49 & 23.78 & 14.17 & 27.16 & 33.40 & 0.0029 & 4.1 \\
\hline $29-2,0-15$ & tr. & 0.57 & 20.76 & 14.91 & 32.91 & 30.85 & 25 & 3.6 \\
\hline $30-3,15-21$ & tr. & 0.41 & 28.05 & 16.16 & 29.78 & 25.61 & 0.0039 & 3. \\
\hline $32-1,31-44$ & 0.21 & 0.32 & 20.77 & 12.06 & 29.28 & 37.35 & 0.0020 & 4. \\
\hline $32-1,81-94$ & 0.26 & 0.52 & 21.03 & 38.36 & 25.86 & 13.96 & 0.0062 & 2.0 \\
\hline $34-3,10-20$ & 0.20 & 0.51 & 26.14 & 18.11 & 40.28 & 14.75 & 0.0050 & 2.6 \\
\hline $34-3,35-37$ & 2.58 & 1.39 & 25.45 & 13.72 & 32.60 & 24.25 & 0.0032 & 3.4 \\
\hline $35-1,110-120$ & tr. & 0.20 & 32.14 & 13.03 & 31.54 & 23.08 & 40 & 3. \\
\hline $35-2,60-70$ & 0.10 & 0.29 & 27.27 & 14.56 & 33.14 & 24.63 & 0.0034 & 3 \\
\hline $37-2,30-40$ & 7.14 & 2.46 & 34.07 & 11.59 & 22.36 & 22.36 & 0.0070 & 4. \\
\hline $37-5,98-110$ & 0.41 & 6.49 & 37.18 & 10.09 & 22.04 & 23.79 & 0.0070 & 4. \\
\hline $48-5,120-130$ & 0.18 & 1.15 & 38.19 & 18.03 & 21.40 & 21.05 & 0.0061 & 3. \\
\hline $48-6,110-120$ & 0.43 & 4.09 & 30.81 & 9.92 & 15.93 & 38.82 & 0.0035 & 7. \\
\hline $51-3,14-16$ & 0.82 & 5.31 & 45.71 & 18.57 & 7.55 & 22.04 & 0.0096 & 3. \\
\hline $51-3,30-32$ & 6.10 & 15.16 & 31.79 & 9.26 & 19.37 & 18.32 & 0.0120 & 4. \\
\hline $51-5,0-12$ & 1.72 & 12.38 & 47.94 & 9.08 & 13.00 & 15.89 & 0.0130 & 2 \\
\hline $51-6,73-83$ & 0.56 & 6.64 & 46.96 & 11.16 & 14.76 & 19.91 & 0.0120 & 3. \\
\hline $53-3,125-135$ & 2.79 & 12.50 & 53.50 & 10.29 & 10.93 & 10.00 & 0.0160 & 2. \\
\hline $54-4,3-13$ & 1.25 & 11.98 & 48.61 & 15.34 & 12.56 & 10.26 & 0.0130 & 2. \\
\hline
\end{tabular}

The sandy and coarse silty materials are usually negligible. Md ranges from 0.0004 to $0.0067 \mathrm{~mm}$; sediment sorting is variable (Table 6, Figure 8).

Interbeds of lithified sediments $(12-2,15-16 \mathrm{~cm})$ represent the clay-calcareous rock of the inequigranular (fine microgranular-pelitomorphic) texture with rhombohedral microcrystals of 0.02 to $0.008 \mathrm{~mm}$ size.

Eopleistocene (Unit 4) is represented by sandy and silty deposits (Core 18) enriched in shell detritus as well as thinly laminated and consolidated calcareous oozes such as lacustrine chalk (Core 19). The grain-size profile of these sediments is variable (Figure 9, Table 6).

The Pliocene sequence consists of three lithologically different units (Figure 8). In the upper one (Unit 5), terrigenous consolidated muds often with a high content of organic matter and diatomic silica prevail. The medium-pelitic and subcolloidal fractions are most prominent, the latter being con- stantly dominant. The amount of sandy and coarse-silty material is commonly less than 1 per cent (Table 6). Fine aleuritic fractions with a high content of diatoms increase in interbeds of low siliceous diatomaceous muds (Core 26, Section 3; Core 27, Section 2; Core 28, Section 3; Core 29, Section 2; Core 30, Section 3). Md of these sediments is 0.0018-0.0039 mm.

An interbed of siderite $(27-3,77-79 \mathrm{~cm})$ is characterized by the microgranular relict-diatomic texture.

Carbonate varves (calcareous and high calcareous thinly laminated oozes enriched in diatoms) prevail in Unit 6. Highly calcareous oozes $(32-1,81-94 \mathrm{~cm}, 34-3,10-20 \mathrm{~cm})$ correspond to the well-sorted pelites with $\mathrm{Md}=0.005-0$ $0062 \mathrm{~mm}$ and So $=2 \cdot 0-2.6$. They contain a small subcolloidal fraction and increased contents of coarse-pelitic or medium pelitic ones. This is a characteristic feature of their grain-size profile. In low calcareous and calcareous sedi- 
SITE 381

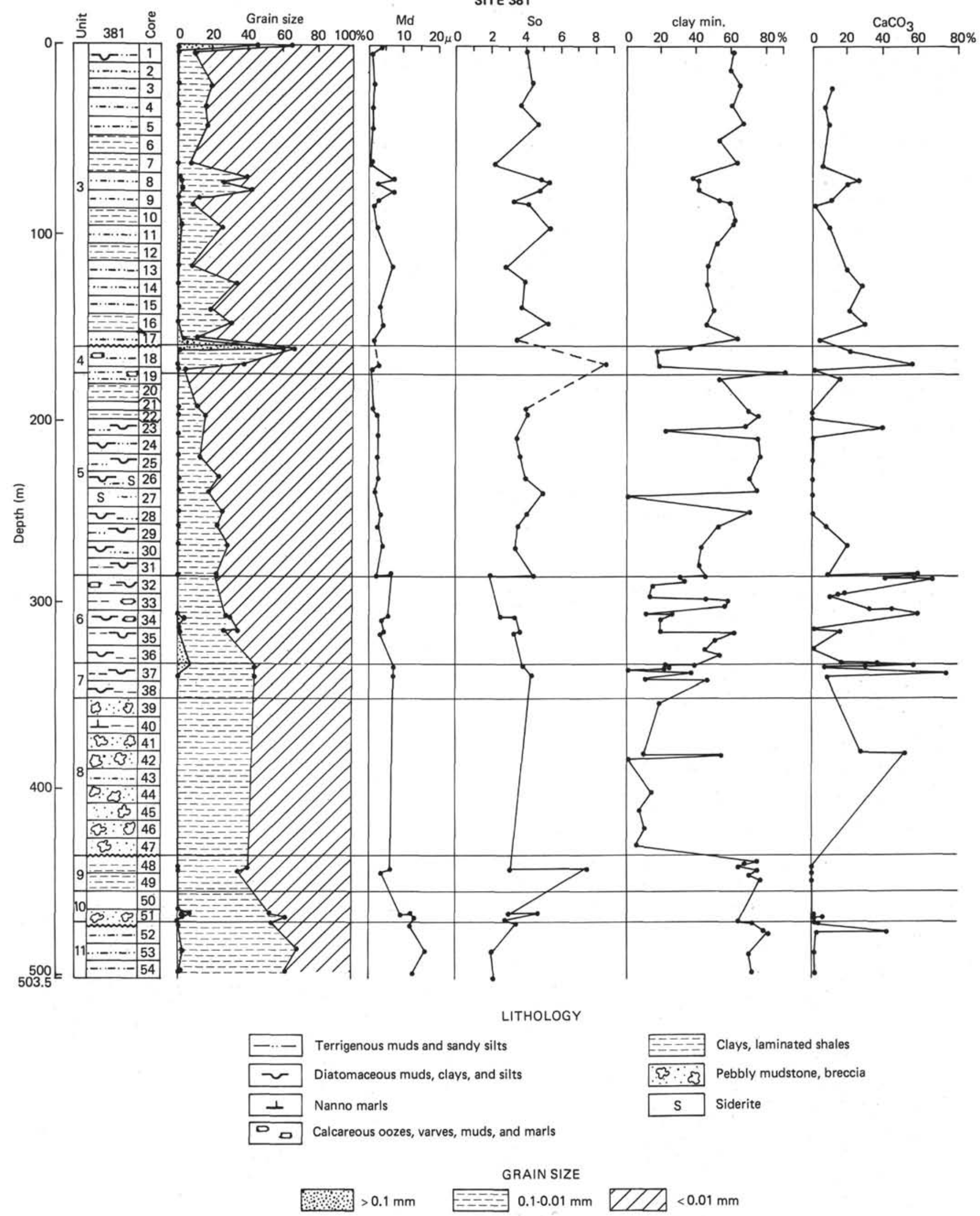

Figure 8. Grain-size fractions, Md and So, Site 381.

ments $(34-3,35-37 \mathrm{~cm}, 35-2,60-70 \mathrm{~cm})$, the fine aleuritic and medium pelitic fractions $(\mathrm{Md}=0,0032-0.0034 \mathrm{~mm}$ ) dominate as well as in aleurite-pelitic muds (35-1, 110-120 $\mathrm{cm})$. 
SITE 381

UNIT 3
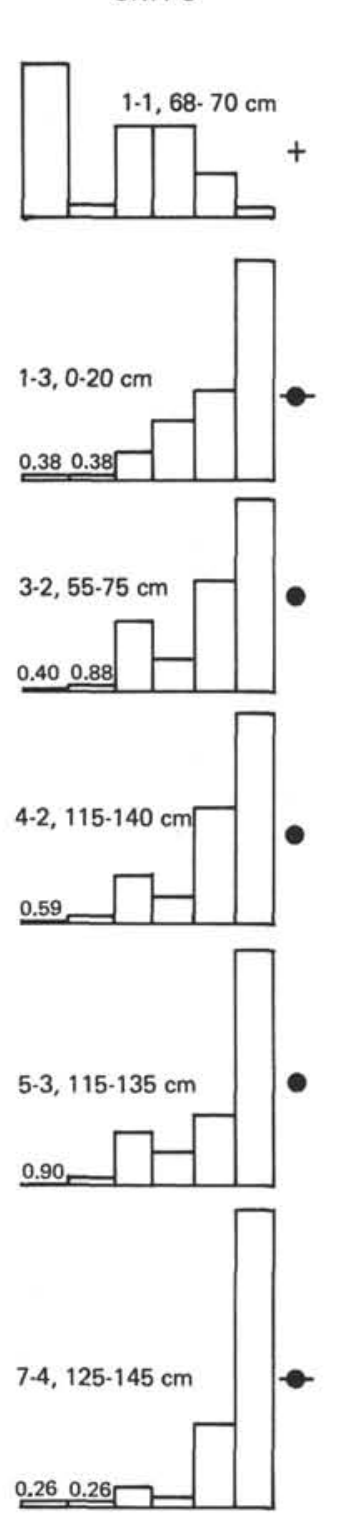

8-3,

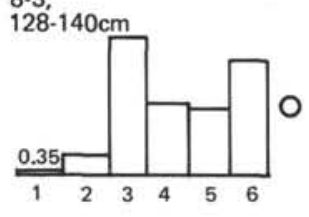

UNIT 4
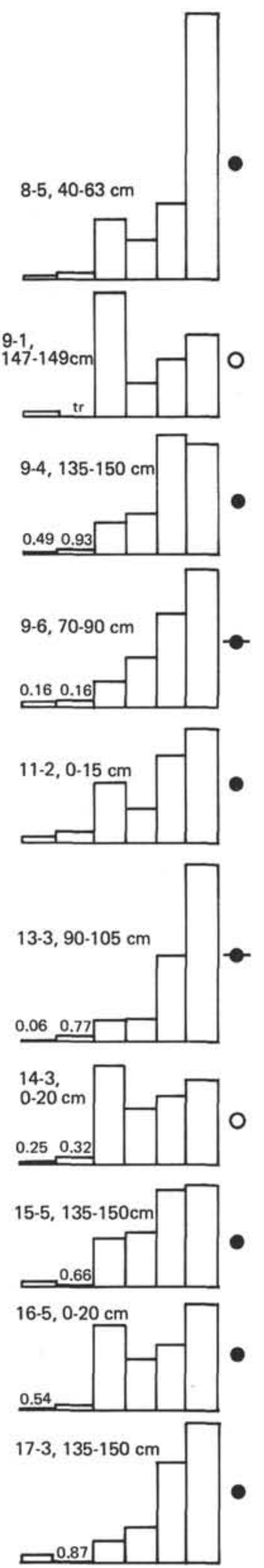

UNIT 5
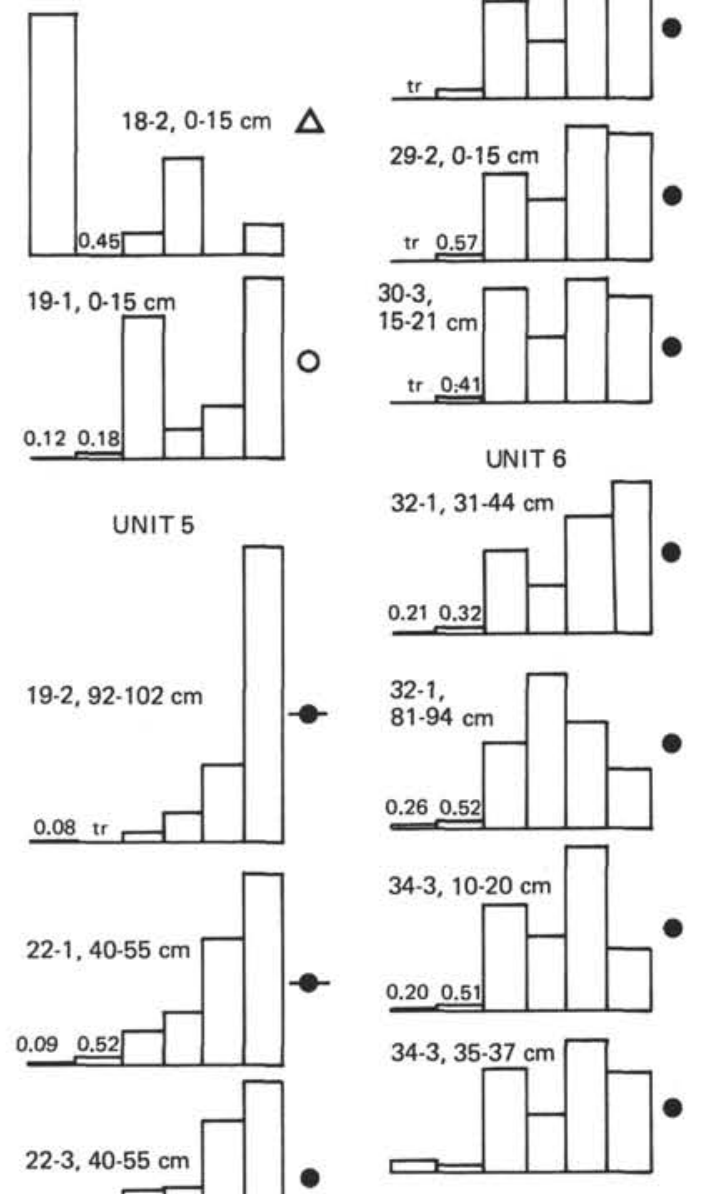

0.200 .5
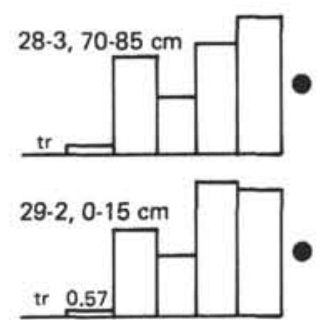

30-3,

$15 \cdot 21 \mathrm{~cm}$

tr $0: 41$

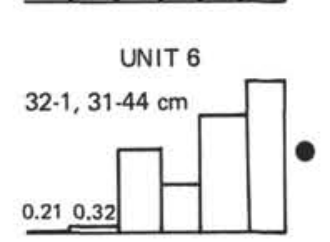

32-1,

$81.94 \mathrm{~cm}$
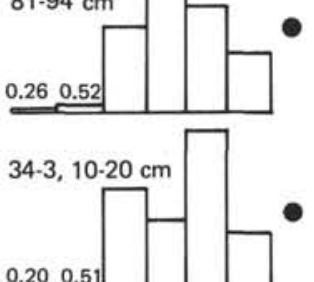

$34-3,35$
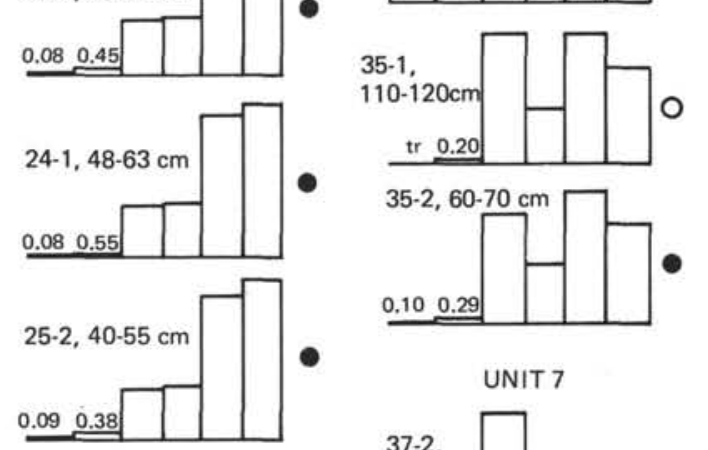

$$
0.100 .2
$$
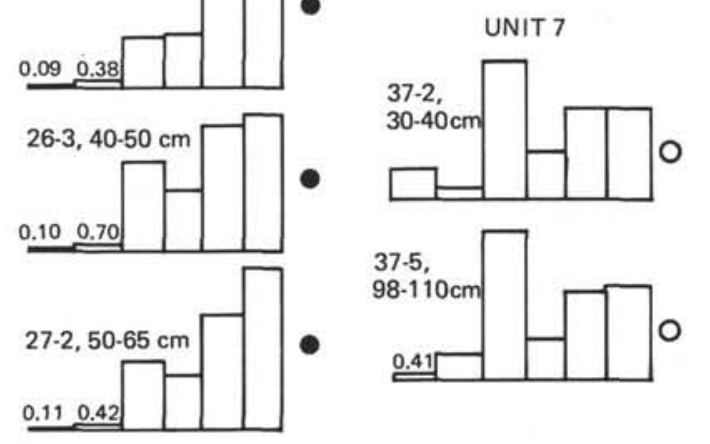
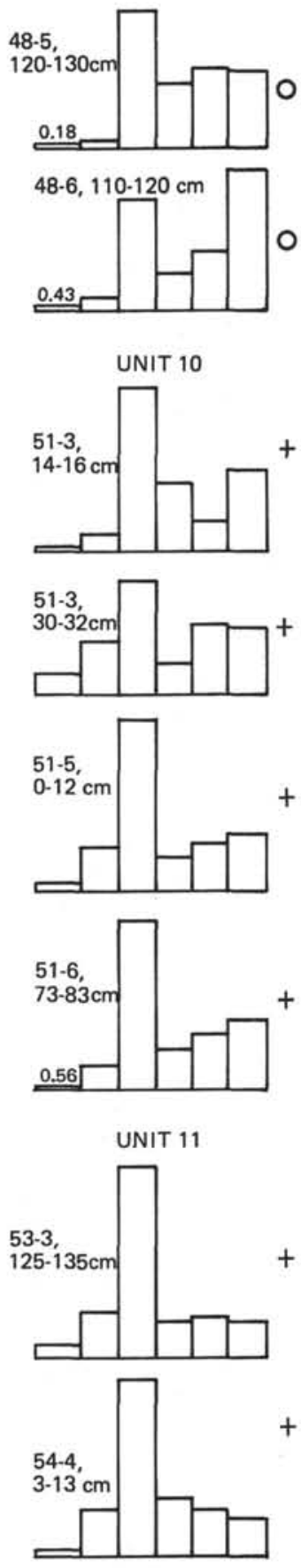

Figure 9. Grain-size histograms of Site 381 sediments.

The lower Pliocene part (Unit 7) is represented by alternating muds with various amounts of carbonates (including aragonitic interlayers) enriched in organic matter and diatoms. The grain-size composition was studied in two samples $(37-2,30-40 \mathrm{~cm}, 37-5,98-110 \mathrm{~cm})$ containing a low content of $\mathrm{CaCO}_{3}$ (less than $10 \%$ ). They are silty clays with a 
prevailing fine aleuritic fraction consisting principally of diatoms. Pelitic material is low $(55.92 \%$ to $55.31 \%)$ and relatively large amounts of coarse aleuritic and partly sandy fractions are in them.

The upper part of the Miocene sequence (Unit 8) consists of unconsolidated sand, gravel, mollusc shells, and lithified dolomite fragments. The studied samples are dolomitic clayey sediments with aleurite-microgranular-pelitomorphic texture $(39-1,42-44 \mathrm{~cm})$, microgranular (principally grain sizes are $0.01-0.005 \mathrm{~mm})$ dolomite $(42, \mathrm{CC})$, fine-pebbled conglomerate (44, CC), conglomerate-breccia $(45, \mathrm{CC})$, and quartzy arkose (46, CC, 47, CC), cemented by microgranular dolomitic (corrosive) cement.

Dark, thinly laminated consolidated clays in Unit 9 are characterized by a cyclic pattern beginning with a sand to silt at the base and ending with clay (without gradual transition). The analysis shows that the grain-size composition of cyclic sediments correspond to aleurite-pelitic muds $(\mathrm{Md}=$ $0.0035-0.0061 \mathrm{~mm}$ ), where fine aleuritic and subcolloidal fractions prevail.

Unit 10 consists of soft sediments with brecciated structure and slumped blocks. Principally they are fine silty muds with $\mathrm{Md}=0.0096-0.0130 \mathrm{~mm}$. In their grain-size profile the fine aleuritic fraction is dominant; as a rule, a noticeable admixture of sandy and coarse silty material is present there (Table 6, Figure 9).

Well-sorted, fine silty muds with scarce clayey-sideritic interbeds of microgranular texture occur in the lower site part (Unit 11).

Some grain-size peculiarities occur in sediments at Site 381. Interglacial deposits (Mindel-Riss) are represented mainly by muds and clays (pelitic and finely dispersed) with rare silt interbeds. Glacial deposits (Mindel) are distinguished by broad ranges in carbon content and are characterized by a wide grain-size spectrum, from silts to finely dispersed pelitic muds and clays. Pelitic and aleurite-pelitic muds prevail. Finely dispersed pelitic sediments are often low calcareous and form interbeds in different parts of the sequence.

Pelitic sediments alternate with aleurite-pelitic ones in the Eopleistocene-Pliocene sequence which is composed of clay and carbonate varves (Units 4-7) enriched in organic matter and diatomic silica (low siliceous deposits). Miocene sediments are also characterized by clay and silty clay lamination.

Rare interbeds of microgranular lithified calcareous clayey sediments (dolomitic clayey, dolomitic, sideritic, etc.) of microgranular-pelitomorphic texture occur in the Pliocene-Miocene sequence.

\section{SUMMARY}

Non-uniform grain-size composition of glacial and interglacial deposits is a common characteristic feature of all the sites. As a rule, glacial units are essentially enriched in sandy silty sediments and turbidites compared to interglacial ones. In both cases finely dispersed pelitic oozes and muds alternating with coarse-grained material are widespread.

Turbidites of both glacial and interglacial units are abundant in Hole 379A. In this case, besides silty sediments, sands and coarse silts are of primary importance in glacial units. Finely dispersed pelitic sediments are most prevalent in Holes 380/380A.
Turbidite distribution in the Pleistocene sequence, particularly in glacial units, is closely connected with sea-level fluctuations. It is possible that the maximum development of turbidites corresponds to the lowest sea level; this was noted previously when turbidite distribution in upper Würm sediments of the Black Sea was examined (Emelyanov and Shimkus, 1963; Shimkus et al., 1975). Turbidites were also formed during periods of high sea level, but not as often and with more local distribution.

The frequent change of grain-size types in glacial and intergłacial units appears to be linked mainly with the mechanical differentiation of the sedimentary material by streams and turbidity currents rather than with compositional changing. Fluctuations of cyclonic surface water circulations and halistatic areas play a large role in the appreciable change of the grain-size profile of pelitic and aleurite-pelitic muds. The most finely dispersed pelitic sediments accumulated in halistatic areas; usual pelitic and aleurite-pelitic ones were formed at their periphery. The formation of fine silty muds, coarse silts, and sands in a deep-sea region results from turbidity current action. Frequent changing of grain size seems to reflect rapid alterations of the hydrodynamic conditions in the basin.

Although the Leg 42B sites are beyond the present western and eastern halistatic areas, interbeds of finely dispersed pelitic sediments that occur in the sections of the sites indicate that formerly they were within ancient halistatic regions. Under the modern environment, finely dispersed oozes and muds accumulate only in halistatic areas (Shimkus and Trimonis, 1974).

Finely dispersed pelitic sediments of Holes 380/380A and 381 were formed in an ancient western halistatic area, which was displaced southwestward relative to the modern one. The sources supplying this region were distant, which permitted considerable grain-size differentiation of sedimentary material en route. In addition, the largest plain rivers coming from the northwest carried mainly finely dispersed sediments.

Episodical accumulation of silty material in pelitic, aleurite-pelitic, and fine silty muds was linked with eolian activity.

\section{REFERENCES}

Bezrukov, P. L. and Lisitzin, A. P., 1960. Klassifikaciya osadkov sovremennych vodoiomov (Classification of sediments of the modern basins): Trudy In-ta okeanol. AN SSSR, v. 32 .

Emelyanov, E. M. and Shimkus, K. M., 1962. K voprosu ob izuchenii izmenchivosti glubokovodnych osadkov Chernogo morya (On the question of variability of deep-water sediments of the Black Sea): Okeanologiya, v. 11, p. 1040-1049.

, 1963. Novye dannye o glubokovodnych novoevksinskich otlozheniyakh Chernogo morya (New data on the deep-water neweuxinic deposits of the Black Sea): Okeanologiya, v. 3, p. 482-494.

Lisitzin, A. P., 1956. K obrabotke rezultatov mekhanicheskogo analiza morskykh osadkov (To the processing of the mechanical analysis results of marine sediments): Trudy In-ta okeanol. AN SSSR, v. 19.

Petelin, V. P., 1961. Noviy metod vodnogo mekhanicheskogo analiza morskykh osadkov (New method of the watermechanical analysis of marine sediments): Okeanologiya, v. 1, p. 143-148.

Prokoptsev, N. G., 1964. K metodike mekhanicheskogo analiza pelitovykh frakciy morskykh osadkov (suspenzionnye vesy) (On the method of mechanical analysis of pelite fractions of marine 
sediments-suspensive balance): Okeanologiya, v. 4, p. 699 707.

Shimkus, K. M. and Trimonis, E. S., 1974. Modern sedimentation in Black Sea. In Degens, E. T. and Ross, D. A. (Eds.), The Black Sea-geology, chemistry and biology: Am. Assoc. Petrol. Geol. Mem. 20, p. 249-278.

Shimkus, K. M., Emelyanov, E. M. and Trimonis, E. S., 1975. Donnye otlozheniya i cherty pozdnechetvertichnoi istorii Cher- nogo morya (Sea-floor sediments and the Late Quaternary history of the Black Sea). In Bulanzhe, Yu. D. et al. (Eds.), Zemnaya kora i istoriya razvitiya Chernomorskoi vpadiny, Izd: Moscow (Nauka), p. 138-163.

Trimonis, E. S., 1972. Sovremennoe osadkoobrazovanie v Chernom more (Modern sedimentation in the Black Sea): Avtoref. kand. diss., Moscow. 